\title{
Microalgae to Energy
}

\author{
Olushola $0^{1 *}$ and Soares Dias AP ${ }^{2}$ \\ ${ }^{1}$ Instituto Superior Técnico, Lisboa, Portugal \\ ${ }^{2}$ Professor, Chemical Engineering, Instituto Superior Técnico, Portugal
}

*Corresponding author: Olapade Olushola, Instituto Superior Técnico, Lisboa, Portugal, Tel: +48513743077; Email: olusolatomy@yahoo.com

\section{Research Article}

Volume 4 Issue 2

Received Date: March 21, 2020

Published Date: June 01, 2020

DOI: $10.23880 /$ ppej-16000223

\section{Abstract}

Microalgae, an organism which is considered as a potential source of biofuel from the last decade endowed with excellent capability of $\mathrm{CO}_{2}$ capture and sequestration, water treatment, prolific growth rate and enormous energy content. The Soxhlet extraction of lipids from microalgae (Chlorella Vulgaris, Nannochloropsis sp., and Thalassiosira weissflogii), was carried out with several solvents (methanol, ethanol, isopropanol, acetone, and hexane), pure and mixtures, in order to optimize the extraction process. For the paper, the highest amount of lipid was obtained using a combination of methanol and acetone or methanol alone. The extract liquid fractions were treated with activated carbon to remove the green pigment. Attempts to in situ algae oil transesterification were accomplished using acid $\left(\mathrm{H}_{2} \mathrm{SO}_{4}\right)$ and base $(\mathrm{NaOH}$ and $\mathrm{CaO})$ catalysts. The extend of extraction processes was assessed by infrared spectroscopy.

Keywords: Renewable energy; Microalgae; Catalysts; Lipid extraction; Catalysis; In situ transesterification

\section{Introduction}

The petroleum reserves of today were simply a legacy of phytoplankton that grew over hundreds of millions of years ago, which were subjected to suitable conditions such as high pressure, temperature, anoxic conditions, and suitable formations and traps. The Present-day descendants of these sources of fossil energy, microalgae, still possess this unique ability to produce the same energy rich compounds that made their ancestors important to the development seen in our modern society. The that chemical engineers and energy technologist can still explore the ability of microorganisms that undergo photosynthesis has gained much interest recently amongst the scientific community [1] (Figure 1).

From the angle of renewability, dirty fuels like coal, oil, and gas are quite good and easy sources of energy and burning them to meet the societal energy demand is also a mature technology. However, this is plagued with a major problem: fossil fuel resources are finite and not renewable. Biomass, on the other hand, grows and is renewable.
Accordingly with data from BP Statistical Review of World Energy, 2018, shows that the proven reserves are currently: Coal - 1,139 billion tonnes, Natural Gas ,-187 trillion cubic meters, and Crude 0il - 1,707 billion barrels, and based on this data matching with current consumption, the remaining life for coal would be 134 years, 53 years for Natural Gas, and 50 years for Crude oil, so in short, the proven reserves would soon be out by the years 2169,2068 for coal and natural gas, respectively, and 2066 for Crude Oil (Figure 2).

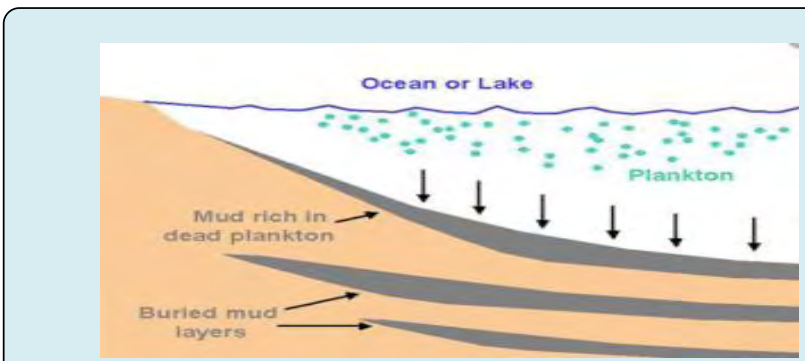

Figure 1: Process of oil formation from phytoplanktons millons of years ago. 


\section{Petroleum \& Petrochemical Engineering Journal}

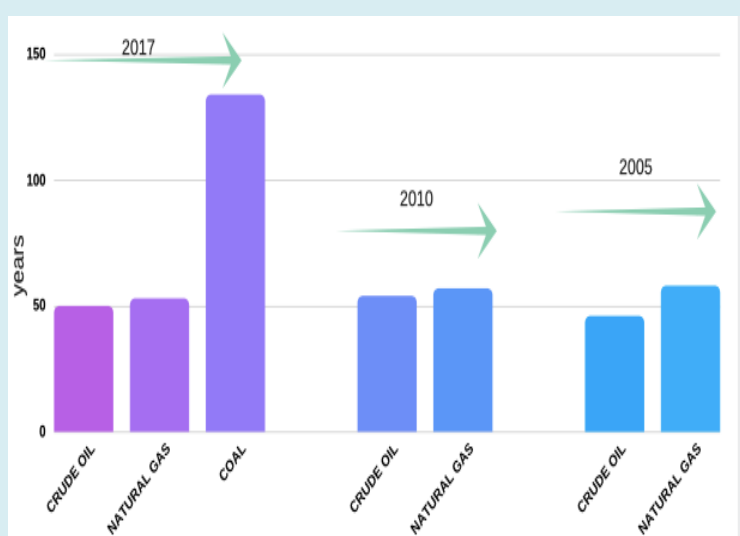

Figure 2: End of fossils fuel based on proven reserves for year 2005, 2010, 2017(BP Statistical Review of World Energy).

\section{Aim and Objectives}

The goal of this paper is to investigate the feasibility of obtaining biofuel from $3^{\text {rd }}$ generation biomass, the factors affecting the technical and economic feasibility of obtaining a cost-effective energy (biofuel) from Microalgae, and the factors hindering the commercial viability.

This dissertation was carried out in the context of the project new processes for fuel production for road transportation (PTDC/EMS-ENE/4865/2014).

\section{Microalgae}

Microscopic algae, also called microphytes, are simply unicellular organisms which are ubiquitous, their presence could be seen in any kind of water varying from freshwater to marine systems depending on the species primarily in pigment composition, biochemical constituents and life cycle, size which could vary from a few micrometres $(\mu \mathrm{m})$ to a few hundred micrometres [2].

\section{Types of Microalgae}

In their research Deng [3], observed that microalgae can be found in a large range of places where light and water are present including ocean, lake, soils, ice, and rivers and that Microalgae can be divided into categories depending on their pigmentation, biological structure and metabolism.

\section{Size Classification}

Microalgae are small organisms, which can be divided into 4 size categories as the microplankton (20 to $1000 \mu \mathrm{m})$, the nanoplankton ( 2 to $100 \mu \mathrm{m})$, the ultraplankton $(0.5$ to $15 \mu \mathrm{m})$ and the picoplancton $(0.2$ to $2 \mu \mathrm{m}$ [4]. Their small size allows them to do an effective photosynthesis, converting light energy with $\mathrm{CO}_{2}$ dissolved in water to produce lipids, carbon hydrates, proteins, etc. [5].

\section{Taxonomic Groups}

There are 4 main taxonomic groups that microalgae can be classified into which are:

1. Diatoms (Bacillariophyceae),

2. Green algae (Chlorophyceae),

3. Cyanobacteria or blue green algae (Cyanophyceaes) and

4. Golden algae (Chrysophyceae).

However, 6 other groups of microalgae exist, which includes the yellow-green (Xanthophyceae), golden algae (Chrysophyceae), red algae (Rhodophyceae), brown algae (Phaeophyceae), dinoflagellates (Dinophyceae), Prasinophyceae, and Eustigmatophyceae [6].

However, unlike the other groups of microalgae, which have lower lipid content and productivity compared with green algae or diatoms, Botryococcus sp., Dunaliella sp. and Chlorella sp. are examples of green algae taxonomic group that are reported to be the most promising species of microalgae for biodiesel production [7] (Table 1).

\begin{tabular}{|c|c|c|c|}
\hline Microalgae & Known Species & Storage Material & Habitat \\
\hline Green Algae & 8000 & Starch and TAGs & Freshwater \\
\hline Blue green algae & 2000 & Starch and TAGs & Freshwater \\
\hline Golden Algae & 1000 & TAGs and carbohydrates & Oceans, fresh and brackish water \\
\hline Diatoms & 100000 & Carbohydrates and TAGs & .
\end{tabular}

Table 1: Four most important microalgae groups in terms of abundance [8].

In comparison to higher plants, microalgae do not have roots, stems, or leaves, but they have higher photosynthetic efficiency than plants or trees. Therefore, microalgae biomass cultivation will help in reducing concentration of $\mathrm{CO}_{2}$ in the atmosphere at a faster rate than other land-based crops, especially when microalgae are cultivated under optimized environment conditions [9]. 


\section{Petroleum \& Petrochemical Engineering Journal}

Microalgae have received a lot of attention because they grow quiet fast, adapt to their environment easily, and their unique ability to concentrate useful chemicals and capture nutrients in an economical way.

\section{Cellular Microalgae}

Cells can be classified in two main groups: eukaryotes and prokaryotes. The distinguishing factor is the presence of nucleus, and the flotation of the DNA in the cell, and these characteristics are absent in prokaryotes.

Microalgae, generally, are consists of eukaryotic cells. These cells therefore have nucleus and organelles. All microalgae have chloroplasts, the bodies with chlorophyll and other photosynthetic pigments which carry out photosynthesis. In Figure 3 it is shown an example of eukaryotic and prokaryotic algae cells with its different dimensions. Examples of prokaryotic microalgae are Cyanobacteria, and of eukaryotic microalgae are green algae, golden brown algae and diatoms [10].

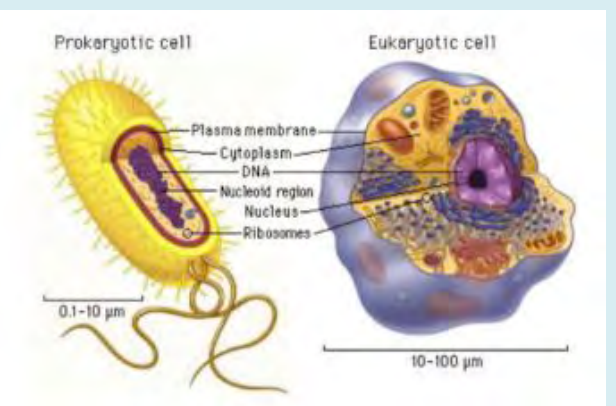

Figure 3: Schematics of Scheme of prokaryotic and eukaryotic cells [11].

In comparison to higher plants, microalgae do not have roots, stems, or leaves, but they have higher photosynthetic efficiency than plants or trees. Therefore, microalgae biomass cultivation will help in reducing concentration of $\mathrm{CO}_{2}$ in the atmosphere at a faster rate than other land-based crops, especially when microalgae are cultivated under optimized environment conditions [9].

Microalgae have received a lot of attention because they grow quiet fast, adapt to their environment easily, and their unique ability to concentrate useful chemicals and capture nutrients in an economical way (Figure 4).

They constitute the most fundamental positions in aquatic ecosystems, and therefore form the basis of food chains. The total biomass they represent is large enough to influence global climate systems. Estimates suggest that some 800,000 species of microalgae exist, yet of these only
50,000 have been documented [13].

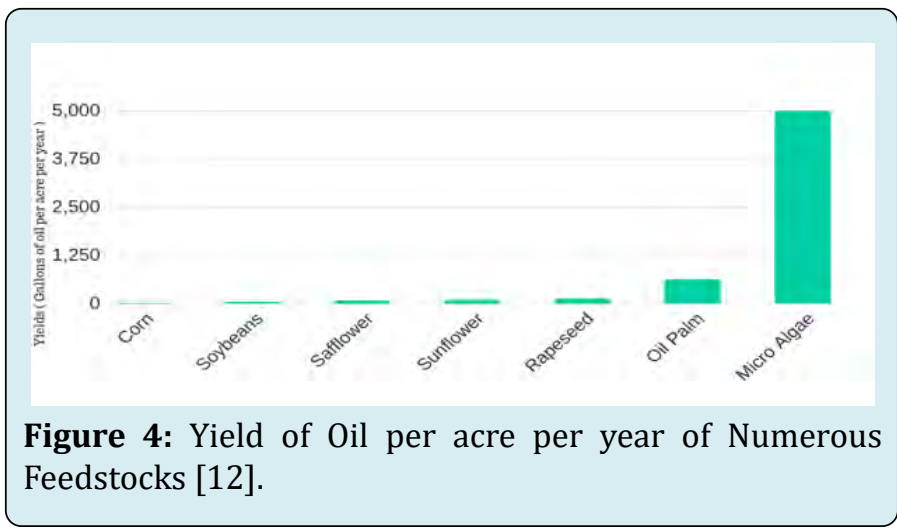

Each species is unique, as they can adapt to a particular environment, for example extreme climates, salt levels, $\mathrm{pH}$ or light levels [14]. This demonstrates the enormous potential for modification of microalgae, which in turn may lead to an alternative resource pool for today's resource limited world.

\section{Photosythesis in Microalgae}

A basic understanding of photosynthesis is fundamental for microalgae biotechnology. Just like plants undergo Photosynthesis, it is so interesting to know that microalgae also experience the same redox process (Equation 1), in which carbon dioxide is converted to carbohydrates and oxygen is released as a side product, the water is oxidized (loses electrons) and the $\mathrm{CO}_{2}$ is reduced (gains electrons).

$$
6 \mathrm{CO}_{2}+12 \mathrm{H}_{2} \mathrm{O}+\text { sunlight } \rightarrow \mathrm{C}_{6} \mathrm{H}_{12} \mathrm{O}_{6}+6 \mathrm{O}_{2}+6 \mathrm{H}_{2} \mathrm{O}
$$

As the cells have enough energy available for photosynthesis, an accumulation of organic matter inside them takes place. The culture is thus able to reproduce by cellular division and increase the number of cells per volume cells density [15]. On a cellular scale, photosynthesis is also an endothermic reaction with the energy input relying on the pigments inside the cells, meaning that these biomolecules initiate the connection between the incident light and the chemical reactions of this metabolic process.

Depending on the wavelength of the incident light, an amount of electrons from some pigment may get excited, passing through a higher energy level on which they become reactive and may start the photosynthesis reaction [16]. The energy amount required to initiate photosynthesis is the one contained in the photon of wavelength of $680 \mathrm{~nm}$, which simple implies that almost all photons from the Photosynthetically active radiation interval overcomes this value (the energy amount of one photon is inversely proportional to its wavelength, as show in Equation 2 below) 


\section{Petroleum \& Petrochemical Engineering Journal}

Where;

$$
E=h * f=\frac{h * c}{\ddot{e}}(2)
$$

$\mathrm{E}=$ total energy flux density $\left(\mathrm{W} / \mathrm{m}^{2}\right)$

$\mathrm{h}=6.6256 \times 10^{-34} \mathrm{~J} \leqslant=$ the Planck's constant

$\mathrm{f}=$ the frequency in hertz, which depends on $\mathrm{t}$

$\lambda=$ wavelength

Photosynthesis is traditionally split into two stages:

1. The light reactions, and

2. The dark Reactions.

Light Reaction is the primal stage in the oxygenic photosynthesis reaction where water is split in the chlorophyll molecule into ions of $\mathrm{H}^{+}$and $\mathrm{OH}^{-}$in the grana of chloroplast, in the presence of light resulting in the formation of assimilatory powers such as NADPH2 (nicotinamide adenine dinucleotide hydrogen phosphate) and ATP (Adenosine triphosphate) [17]. Dark Reaction, the second step of the oxygenic photosynthesis redox reaction, which is independent of light, takes place in the stroma of the chloroplast. It is slower than the light reaction, and in this stage the NADPH and ATP are utilized in the sequential biochemical reduction of carbon dioxide to carbohydrates (Figure 5).

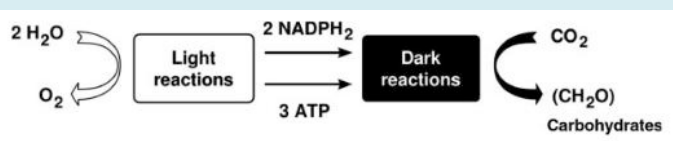

Figure 5: Light and Dark Redox Reaction.

\section{Biofuels Production from Microalgae}

Apart from its biofuel production capabilities, Microalgae can be utilized as sources of many products including chemicals (vitamins, pigments, antioxidants), oils (omega-3 fatty acids), protein, animal feed (for larval bivalves), and biomass for the production of ethanol and methane [18]. Biodiesel production from Microbial oil (MA) is significantly gaining interests due to the following reasons listed below [18]:

1. Rapid growth rate, usually two weeks from innoculation to harvesting,

2. High lipids content as compared to other crops,

3. Problems on utilization of petrodiesel (depleting nature of proven reserves of fossil fuels),

4. Increase in the price of vegetable-based biodiesel and its increasing competition with food,

5. The possibility of using non-arable land for MA cultivation.
Though there is a continuous effort to increase its lipid content and productivity, and one of the solution proffered is the use of genetic engineering (GE) technologies, there is still a controversy between science and environment about the risk posed by MA that are not cultivated for nonconsumptive purposes present less risk when exposed to humans, but the effect on the environment is not yet resolved. GE technologies could help increase lipid content, pathogen resistance attributes, and high value of co-products [19].

Nonetheless, algae biofuel conversion methods, such as transesterification, fermentation, and hydro-treatment, are more complex and economically expensive when compared to fossil-derived fuels and even biofuels from other feedstocks [20].

\section{The Market of Microalgae Biofuel}

On a global scale, major oil producing countries have shown great interest in biofuel and renewable energy, leading them to setting specific future goals and targets about the production as well as applications of biofuels. Countries like UAE have planned to run $10 \%$ of its transportation on biofuel by 2020 and USA has proposed to substitute $20 \%$ of its road transport fuel for biofuel by 2022 [21]. By 2021, car manufacturers will have to comply with the $95 \mathrm{~g} \mathrm{CO}_{2} /$ $\mathrm{km}$ limit, set by the European Union in order to mitigate $\mathrm{CO}_{2}$ emissions from their fleet of new sold passenger cars [22]. This means that biofuels, as an alternative fuel, will be one of the viable solutions [23]. The Renewable Energy Directive (RED) has also drafted a legislation to increase the production of advance biofuels from microalgae by the year 2020 (Royal Society of Biology).

\section{Economics of Microalgae Biofuel}

The production cost is determined immensely by cultivation mode, and as at February 2007, the estimated cost of producing a kilogram of microalgal biomass is $\$ 2.95$ and $\$ 3.80$ for photo bioreactors and raceways, respectively, with the assumption that carbon dioxide is available at no cost [9]. In 2010, US navy invested 12 million US $\$$ to Dynamic fuels for biodiesel production from Microalgae. The cost of Biodiesel was around \$100/Litres in the first year but dropped to $\$ 7 /$ Litres in 2011 [24]. In 2013, Exxon Mobil concluded its R\&D program on algal biofuel by stating this type of fuel would not be viable for another 25 years. At the end of that program, the company had invested $\$ 600$ million into it [25].

In addition to the Cultivation mode, biomass productivity, the purity of lipids extracted, the plant scale, and the capital investment (land, equipment, and construction) also affects the production costs which were about $\$ 0.8 / \mathrm{L}$ for biodiesel 


\section{Petroleum \& Petrochemical Engineering Journal}

from vegetable oil and $\$ 0.65 / \mathrm{L}$ for petrol-diesel, compared to Microalgal biodiesel around $\$ 3 / \mathrm{L}$, as seen in Table 2 according to the US Department of Energy in 2014.

According to the research of Vincent Amanor-Boadu [26], and Sawaengsak W [27], MA biodiesel is still far from being affordable, though some countries have the policy to give subsidies for biodiesel production, which was around 0.26 US \$ to 0.40 US \$/L, after which biodiesel production from microalgae was still not comparable with vegetable biodiesel and petro-diesel.

\begin{tabular}{|c|c|c|c|c|}
\hline $\begin{array}{c}\text { Type of } \\
\text { cultivation }\end{array}$ & Process & Conditions & $\begin{array}{c}\text { Lipid cost } \\
\text { (US \$/L) }\end{array}$ & $\begin{array}{c}\text { Biodiesel } \\
\text { cost (US \$/L) }\end{array}$ \\
\hline $\begin{array}{c}\text { Open pond } \\
\text { cultivation }\end{array}$ & $\begin{array}{c}\text { Dewatering; lipid extraction from } \\
\text { dry biomass; transesterification }\end{array}$ & $\begin{array}{c}\text { Capacity:1950 ha; Biomass yield: } 25 \mathrm{~g} / \\
\mathrm{m} 2 / \mathrm{d} \text {; Lipid content: } 25 \% \mathrm{w} / \mathrm{w} \text { dry } \\
\text { biomass }\end{array}$ & 2.25 & 2.6 \\
\hline $\begin{array}{c}\text { PBR } \\
\text { cultivation }\end{array}$ & $\begin{array}{c}\text { Dewatering; lipid extraction from } \\
\text { dry biomass; transesterification }\end{array}$ & $\begin{array}{c}\text { Capacity: } 1950 \text { ha; Biomass yield: } \\
1.25 \mathrm{~kg} / \mathrm{m} 3 / \mathrm{d} \text {, Lipid content: } 25 \% \mathrm{w} / \mathrm{w} \\
\text { dry biomass }\end{array}$ & 4.78 & 5.42 \\
\hline
\end{tabular}

Table 2: Cost of biodiesel production from microalgae in US \$/L (adapted from (Chen J [18], (Davis R [28]).

According to (Chisti Y [29]) in "Biodisel from Bioalgae", MA to potentially completely replace petroleum as a source of hydrocarbon feedstock in the petrochemical industry, it needs to fulfil the correlation of Christi Y [29] (Equation 3 ), which shows the relationship of microalgae diesel price, also Figure 6 shows the output for MA biodiesel for crude oil price between 60 and 65.7 \$/Barrel.

$$
\mathrm{C}_{\text {microalgae oil }}=0.00693 * \mathrm{C}_{\text {crudeoil }}
$$

Where:

$\mathrm{C}_{\text {microalgae oil }}=$ MA biodiesel price in $\$ /$ Liters, and

$\mathrm{C}_{\text {crude oil }}=$ Crude oil price in \$/Barrel.

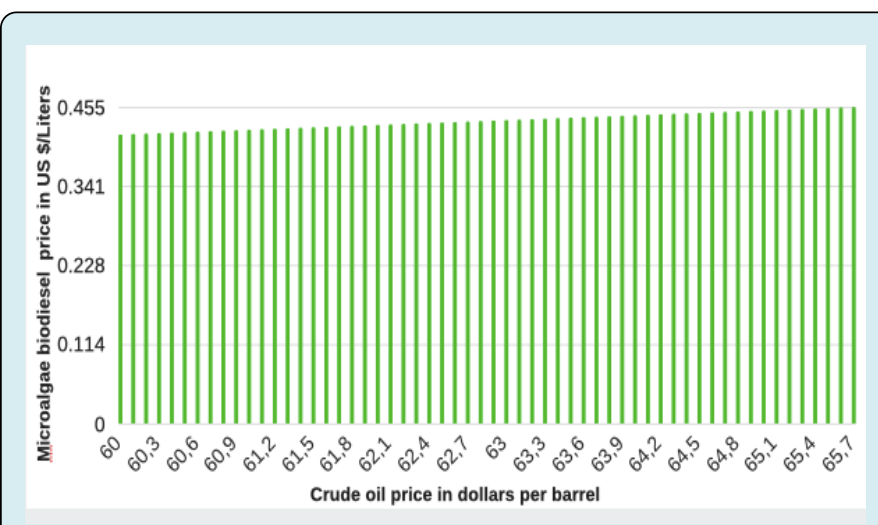

Figure 6: Relationship between Crude oil price in $\$ / \mathrm{BBl}$ and Microalgae Biodiesel in \$/Liters.

By breaking down the total cost needed to produce microalgae biodiesel, Figure 7 shows the pecentage of the total cost needed by each segment of production from cultivation and harvesting, extraction, transesterification, purification, and distributions of the total cost with
Culitvation and extraction taking up to $60 \%$.

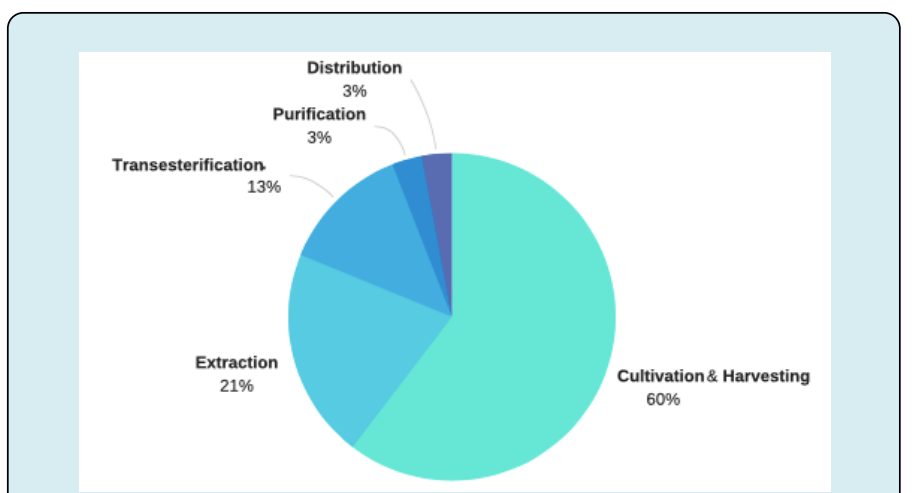

Figure 7: Cost breakdown of Microalgae Biodiesel [29].

Till date no affordable Microalgae biodiesel is produced on a commercial scale, but it is worth investing in the studies of MA as fossil fuels are depleting and price of vegetable oils are gradually increasing.

\section{Microalgae Diesel Price Parity}

The cost reduction required for Microalgae diesel to gain parity with petro-diesel can be achieved through:

1. The biorefinery approach, which involves simultaneous biodiesel production with other co-products just like in the oil and gas refinery where petro-oil is removed with other fractions of crude oil.

2. In addition, advances in engineering of photobioreactors with highly efficient dewatering and extraction technology and studying and improving the technology that combines extraction and transesterification;

3. Improving capabilities of microalgae through genetic engineering, by isolating high productive microalgae 


\section{Petroleum \& Petrochemical Engineering Journal}

strain with lipid content;

4. MA cultivation in rural area, this strategy will bring life to the rural areas both economically and socially, curbing rural urban migration. In reality around $68 \%$ of the Total biodiesel production cost is by the capital expenditure (land, construction, and instrumentation), some researchers also suggested the that use of desert land can reduced the capital expenditure by $4 \%$, for which the land takes $15 \%$ of the investment [29].

\section{Cultivation of Algae Biomass}

The breeding of algae feedstock is a relatively easy task which can be done with little or no aid, using waste water while absorbing $\mathrm{CO}_{2}$ from the atmosphere, but adequate knowledge about algae culturing is required before venturing into commercial cultivation of MA. Table 3 highlights the generalized condition for the cultivation of algae, which include parameters like temperature, salinity, light intensity, photoperiod and $\mathrm{pH}$.

The cultivation methods are classified based on the interaction between the culture and the environment into the:

1. Open systems (where the culture is directly exposed to the environment), and

2. Closed systems (where the culture is wholly enclosed within the culture vessel called the photo-bioreactor).

Open race way ponds, a type of the open system and photo-bioreactor (PBR) are the most applied systems [30].

\begin{tabular}{|c|c|c|}
\hline Parameters & Range & Optima \\
\hline Temperature $\left({ }^{\circ} \mathrm{C}\right)$ & $16-27$ & $18-24$ \\
\hline Light intensity (lux) & $1000-10,000$ (depends on volume and density) & $2500-5000$ \\
\hline Salinity (g/l) & $12-40$ & $20-24$ \\
\hline Photoperiod (light: dark, hours) & $12: 12: 00,18: 06$ & $16: 8(\min ) 20: 0(\mathrm{max})$ \\
\hline $\mathrm{pH}$ & $7-9$ & $8.2-8.7$ \\
\hline
\end{tabular}

Table 3: Generalized conditions for algae cultivation.

\section{Open Race Way Ponds}

The open system methods also include the use of lakes and lagoons, but the most popular is the pond, which are further classified based on natural water bodies, e.g. shallow ponds, circular ponds and raceway ponds [31]. Raceway ponds have been used since the 1950s and it is considered a mature technology. The culture in the ponds must be circulated at about $20-30 \mathrm{~cm} / \mathrm{s}$ to keep the algae suspended as well as to provide relatively even illumination to the algae and prevent thermal stratification [32] (Figure 8).

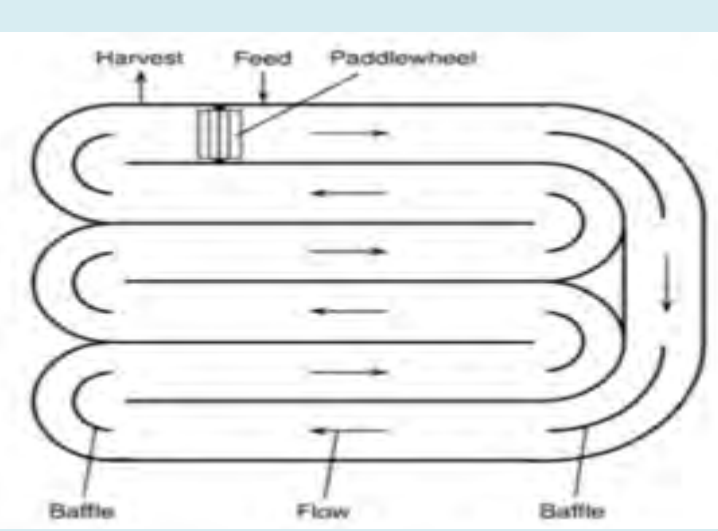

Figure 8: Arial View of a race way pond [29].
The advantages of using these systems are [33]:

1. Mature technology,

2. Simple technology

3. Low energy consumption,

4. Low capital costs,

5. High Net energy ratio $(\mathrm{NER}=8.34)$.

However, despite the advantages listed above, the system has some weaknesses limiting it, which are [33]:

1. High contamination level,

2. High water use (high water footprint)

3. Climatic dependence (annual average temperature > $\left.15^{\circ} \mathrm{C}\right)$,

4. Large land demand,

5. Dilute biomass, and

6. Low productivity, of around $11 \mathrm{~g} / \mathrm{m}^{2} /$ day.

\section{Photo-Bioreactor (PBR)}

Unlike the ponds, a PBR is a closed system equipment/ container where MA can grow and the growth conditions can be controlled. PBRs facilitate better control of culture environment such as carbon dioxide supply, water supply, optimal temperature, efficient exposure to light, culture density, $\mathrm{pH}$ levels, gas supply rate, mixing regime, etc. 


\section{Petroleum \& Petrochemical Engineering Journal}

[18]. There are different forms of PBR, which are mainly tubular and flat panel reactors with Table 4 showing the characteristics of an existing PRB. Other options are bags, coils or domes. The algae in closed systems, depending on their construction, are set into motion by induced $\mathrm{CO}_{2}$ or pumps, as seen in the schmatics of a PBR in Figures $9 \& 10$ below. According to Darzins A, et al. most of the start-ups in the algae biofuel sector focus on photobioreactors (PBR) for the reasons described below:

1. Significantly higher productivity, usually $27 \mathrm{~g} / \mathrm{m}^{2} /$ day;

2. Lower risk of contamination and low water consumption;

3. Low space requirement and excellent purity of the biomass (food grade);

4. High reproducibility of results and constant and predictable production volume;

5. Cost-efficient harvest due to higher algae concentration;

6. The possibility of an easy change of the cultivated algae;

7. Low weather dependency, and the possibility of a $24 \mathrm{~h}$ production with artificial lighting.

But high capital, high operating cost, high energy requirements, and the fact that is a technology in the research phase are the main setback of the PBR [34].

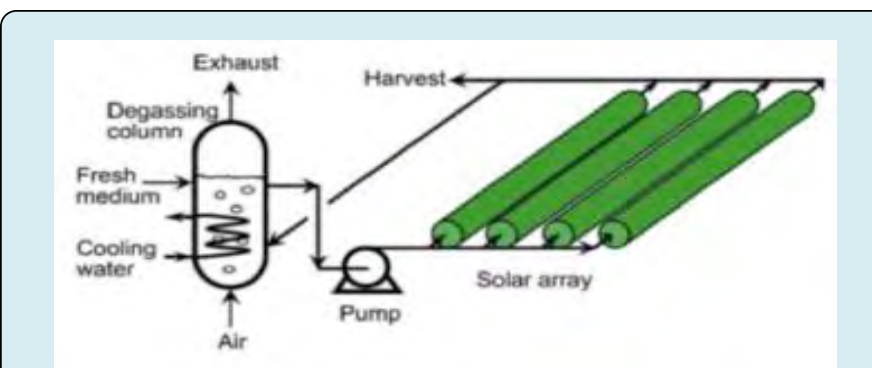

Figure 9: Schematics of PBR with Horizontal tubes.

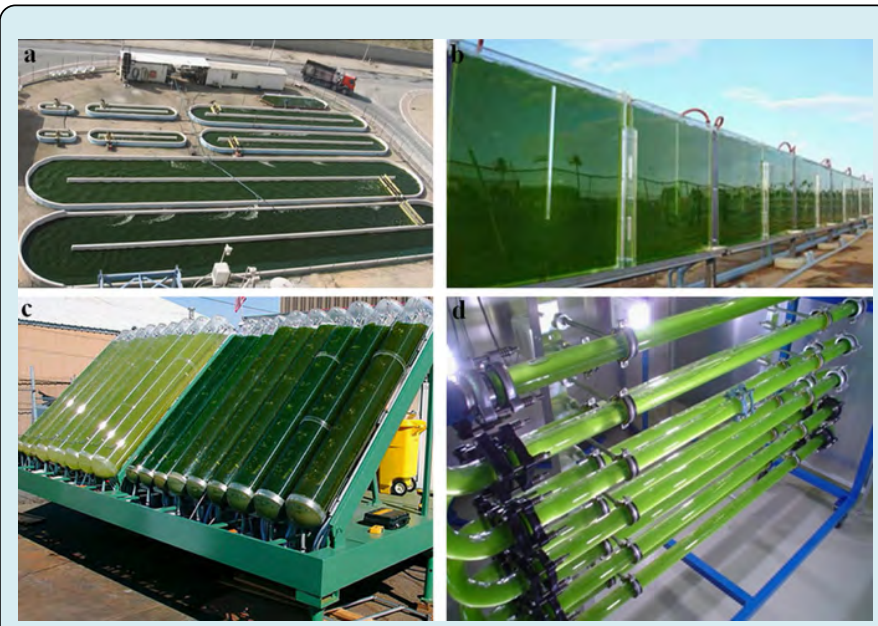

Figure 10: Open and Closed system methods of growing microalgae.

\begin{tabular}{|c|c|}
\hline Characteristics & PBR \\
\hline Number of tubes & 24 \\
\hline Number of collectors & 4 \\
\hline External diameter & $63 \mathrm{~mm}$ \\
\hline Internal diameter & $56 \mathrm{~mm}$ \\
\hline Material & PMMA \\
\hline Vertical distance between axes & $98 \mathrm{~mm}$ \\
\hline Horizontal distance between axes & $185 \mathrm{~mm}$ \\
\hline Length (m) & $18 \mathrm{~m}$ \\
\hline Orientation & $\mathrm{E}-\mathrm{W}$ \\
\hline Maximum temperature & $30{ }^{\circ} \mathrm{C}$ \\
\hline pH (set point) & 8 \\
\hline Tank volume & $350 \mathrm{~L}$ \\
\hline Total volume & $1.4 \mathrm{~m}^{3}$ \\
\hline
\end{tabular}

Table 4: Example of a PBR configuration for a startup.

\section{Application of Microalgae}

Microalgae can be used to produce a wide range of metabolites such as proteins, lipids, carbohydrates, carotenoids or vitamins for health, food and feed additives, cosmetics and for energy production as seen in Figure 11 [35].

The Figure 12 shows that the value of added products is more economically viable, with around 10-100 euro per kilogramme. Furthermore, Microalgae has been reported being used for photobioremediation of toxic waters, treatment of sewage systems, and even cleaning of flue gases produced in power plants, thereby reducing the cost of treatment, the microalgae is fed with the gases as a source of food [36].

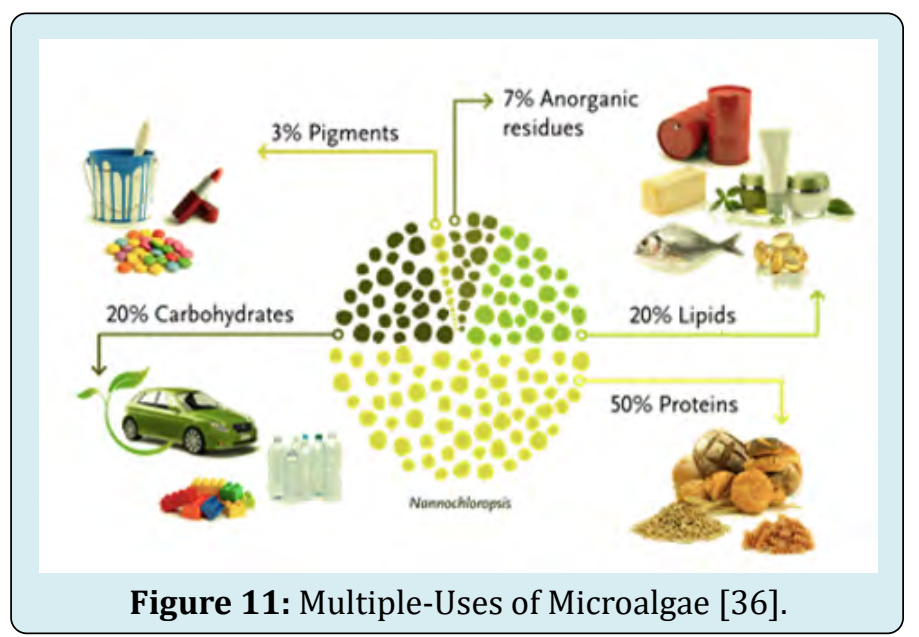




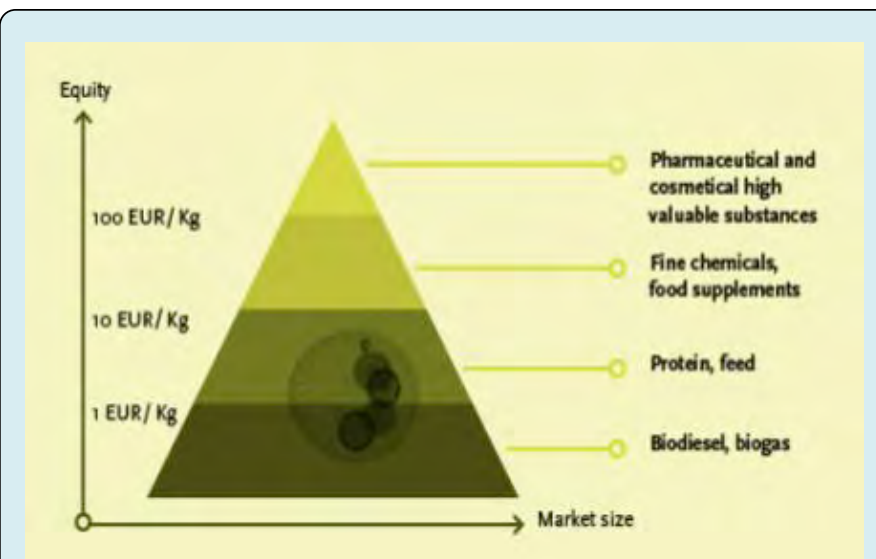

Figure 12: Components from Microalgae and value [37].

\section{Microalgae and Human Food}

The first human use of microalgae for food dates back 2000 years, when the Chinese used "Nostoc" to escape starvation during famine. However, microalgal biotechnology only started receiving attention from the middle of the last century [38]. In the mid $20^{\text {th }}$ century, microalgae gained attention as being a good supplement and/or fortification in diets for malnourished children and adults, as a single cell protein, but nowadays it is marketed in different forms of tablets, capsules and liquids [39].

Aside just being a source of food, the nutritional value of microalgae in human food is one of the most complete source, being so rich in carbohydrate, protein, enzymes, and fibres, also having in abundance are vitamin A, C, B1, $\mathrm{B}_{2}, \mathrm{~B}_{6}$, niacin, iodine, potassium, iron, magnesium and calcium [35]. Research from Pangestuti R, et al. [40] shows that the pigments found in microalgae such as chlorophyll, $\beta$-carotene, and lutein are beneficial to human health, possessing cancer prevention activity and functioning as antioxidants and anti-inflammatories [40]. However, vitamins cell content fluctuates with environmental factors, the harvesting treatment and the biomass drying methods (Brown [41]), (Borowitzka, [42]).

The work of (Alice Ferreira [43]) proved the effectiveness of Scenedesmus obliquous to effectively treat the brewery effluents (liquid and gaseous), with a production of valuable biomass useful for bioenergy production, such as an energy carrier $\mathrm{BioH}_{2}\left(67.1 \mathrm{~mL} \mathrm{H}_{2}\right.$ g1 (in terms of VS)), or the three products bio-oil (64\%), bio-char (30\%) and bio-gas (6\%) from a single pyrolysis process. This work proved that it is possible to integrate several sustainable processes, resulting in a closed loop system that allowed an efficient nutrient recycle (wastes) and the full use of the energy [43] (Table 5).

\begin{tabular}{|c|c|c|c|}
\hline Microalgae & Major Producers & Products & $\begin{array}{c}\text { World production } \\
\text { (t/year) }\end{array}$ \\
\hline \multirow{3}{*}{$\begin{array}{c}\text { Spirulina } \\
\text { (Arthrosphira) }\end{array}$} & Hainan Simai Pharmacy Co. (China) & powders, extracts & \multirow{3}{*}{3000} \\
\hline & Earthrise Nutritionals (California, USA) & $\begin{array}{l}\text { tablets, powders, extracts tablets, } \\
\text { powders, beverages, extracts }\end{array}$ & \\
\hline & $\begin{array}{l}\text { Cyanotech Corp. (Hawaii, USA) Myanmar } \\
\text { Spirulina factory (Myanmar) }\end{array}$ & $\begin{array}{l}\text { tablets, chips, pasta and liquid } \\
\text { extract }\end{array}$ & \\
\hline Chlorella & $\begin{array}{l}\text { Taiwan Chlorella Manufacturing Co. } \\
\text { (Taiwan) Klötze (Germany) }\end{array}$ & tablets, powders, nectar, noodles & 2000 \\
\hline Dunaliella salina & Cognis Nutrition and Health (Australia) & powders b-carotene & 1200 \\
\hline $\begin{array}{l}\text { Aphanizomenon flos- } \\
\text { aquae }\end{array}$ & Blue Green Foods (USA) Vision (USA) & $\begin{array}{l}\text { capsules, crystals powder, } \\
\text { capsules, crystals }\end{array}$ & 500 \\
\hline
\end{tabular}

Table 5: Microalgae for food table, (Adapted from (Spolaore [39]) (Pulz [44]), and (Hallmann [45])).

\section{Oil Extraction Methods}

Microalgae biomass varies from other biomass feedstocks used in the production of biodiesel in the chemistry of cell wall, plasma membrane, the presence of a large amount of water and the small size of the cells. In order to make biodiesel, the extraction of the lipids is necessary, however, the extraction of lipids from microalgae at laboratory scale has been attempted by both mechanical and chemical extraction, with solvent extraction being the most workable approach so far Hidalgo P [46].

\section{Microalgae Lipid}

Lipids are classified into two types, broadly as neutral or polar lipids. A neutral lipid has no overall polarity. It is located inside the cells in the form of triacylglycerides, monoglyceride-and diglycerides or free fatty acids. They are more soluble in non-polar solvents, such as hexane and chloroform. Neutral lipids are energy storage products. The 


\section{Petroleum \& Petrochemical Engineering Journal}

general structure of triacylglycerides is shown in Figure 13 below.

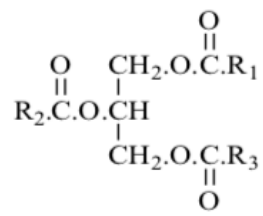

Figure 13: Triglyceride structure.

Polar lipids could be either phospholipids or glycolipids which contains polar groups, such as choline, ethanolamine, serine, water, glycerol, and phosphatidyglycerol in phospholipids. Glycolipids are other form of polar lipid but are less polar than phospholipids. They are simple sugarcontaining lipids. They include monogalactosyl diglyceride, digalactosyl diglyceride and sulpholipids. They are located in the cell walls. They are, as might be expected, more soluble in polar solvents, such as methanol and water. They give cell walls their structural rigidity [33].

Their various structures are listed below in Figures 14 \& 15, where R1, R2, R3 in Figure 13-15 denote fatty acid molecules which could be involved in transesterification process as commonly observed in triglycerides.

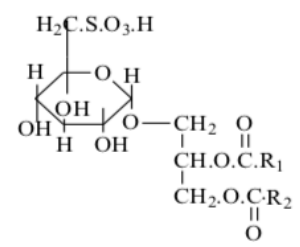

Figure 14: Sulpholipid structure.

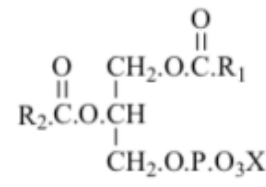

Figure 15: Phospholipids general structure.

Neutral lipids (TAGs) are usually regarded as energy storage products, whereas the Polar lipids like Phospho lipids and Glycol lipids are structural lipids, contained mainly in the cell membranes. The type of species and the time of harvesting of MA determines the lipid composition. MA harvested during the exponential growth phase usually contains more polar lipids (GLs and PLs) than those harvested in the late stationary phase of growth (usual for batch cultures), which contain more neutral lipids (TAGs).
The lipid fractionation procedure and the selection of solvent, or solvent system, will depend on the particular classes of lipids present. Overall, neutral lipids are recovered by nonpolar solvents, whereas polar lipids are recovered by polar ones (Borowitzka MA [47]).

\section{Physical or Mechanical Methods}

Expression/Expeller Press: Dried Algae retains its oil content, which then can be "pressed" out with an oil press. Since different strains of algae vary widely in their physical attributes, various press configurations (screw, expeller, piston, etc) work better for specific algae types. Many commercial manufacturers of vegetable oil use a combination of mechanical pressing and chemical solvents in extracting oil [48].

Ultrasonic-Assisted Extraction: Ultrasonic extraction, a branch of sonochemistry, can greatly accelerate extraction processes like in the case of Ferreira AF, et al. [19], where ultrasound assisted method with solvents extraction was carried on three species of MA. Using an ultrasonic reactor, ultrasonic waves are used to create cavitation bubbles in a solvent material. When these bubbles collapse near the cell walls, it creates shock waves and liquid jets that causes those cells walls to break and release their contents into the solvent.

\section{Chemical Extraction Methods}

MA oil can be extracted using chemicals such as, Benzene and ether. Oil can also be separated by hexane extraction, which is quite used in the food industry and is relatively inexpensive. The downside to using solvents for oil extraction are included in the dangers involved in working with the chemicals. Care must be taken to avoid over exposure to vapours and direct contact with the skin, either of which can be highly dangerous. Benzene is classified as a carcinogen. Chemical solvents also present the problem of being an explosion hazard [49].

\section{Chemical Methods are:}

Hexane Solvent Method: Hexane solvent extraction can be used in isolation or it can be used along with the oil press/ expeller method. After the oil has been extracted using an expeller, the remaining pulp can be mixed with cyclohexane to extract the remaining oil content. The oil dissolves in the cyclohexane, and the pulp is filtered out from the solution. The oil and cyclohexane are separated by means of distillation. These two stages (cold press \& hexane solvent) together will be able to derive more than $95 \%$ of the total oil present in the algae [49].

Soxhlet Extraction: Soxhlet extraction is an extraction method that uses chemical solvents. Oils from the algae are extracted through repeated washing, or percolation, 


\section{Petroleum \& Petrochemical Engineering Journal}

with an organic solvent such as hexane or petroleum ether, under reflux in a special glassware. Pardo-Cárdenas Y, et al. reported that a wide variety of organic solvents are often used to extract oil from microalgae, with hexane and ethanol as the most used solvents. However, ethanol is a polar solvent and its selectivity to lipids is relatively low compared to other solvents, so in extractions with ethanol, other microalgae components may also appear, such as sugars, pigments or amino-acids. Also, in his research using a hexane-ethanol mixture, results showed that approximately $80 \%$ of fatty acids present in biomass can be extracted.

Hexane is cheaper than other non-polar solvents such as cyclohexane; it is easy-to-recover after extraction and is selective to neutral lipids [49]. Veera concluded that solvent mixtures containing mixture of a polar and a non-polar solvent extracts a greater amount of lipids. For example, a combination of chloroform (non-polar), methanol (polar) and water, known as the Bligh \& Dyer method, has been used for lipid extraction from a wide range of biological samples.

Supercritical Fluid Extraction: Although supercritical fluid has liquid-like density, it exhibits gas-like diffusivity, surface tension and viscosity. Its gas-like viscosity results in high mass transfer. Its low surface tension and viscosity lead to greater penetration into porous solids. Because of its liquid-like density, a supercritical fluid's solvent strength is comparable to that of a liquid [50].

In supercritical $\mathrm{CO}_{2}$ extraction, $\mathrm{CO}_{2}$ is liquefied under pressure and heated to the point that it has the properties of both a liquid and a gas, more specifically, it behaves as a supercritical fluid above its critical temperature $\left(\mathrm{T}_{\mathrm{c}}: 32.1^{\circ} \mathrm{C}\right)$, which is near ambient temperature, making it an attractive solvent for temperature-sensitive materials. $\mathrm{CO}_{2}{ }^{\text {'s }}$ critical pressure is 73.8 bar $\left(\mathrm{P}_{\mathrm{c}}: 1.070 \mathrm{psi}\right)$, as shown in its phase diagram (Figure 16) [51].

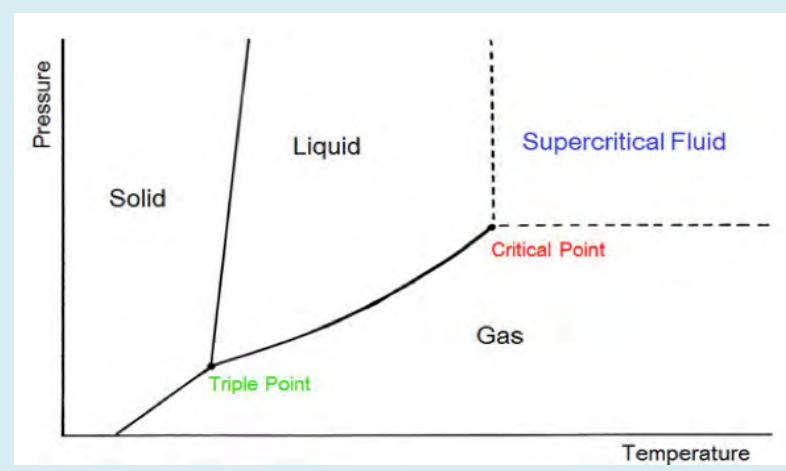

Figure 16: Phase diagram of $\mathrm{CO}_{2}$ showing its supercritical region [52].

Supercritical $\mathrm{CO}_{2}$ is becoming an important commercial and industrial solvent due to its role in chemical extraction in addition to its low toxicity and environmental impact. Typical methods of extracting oil from MA has some drawbacks [53].

1. MA biomass is required to be in form of a powder prior to traditional solvent extraction process for high efficiency extraction of lipids which is quite energy intensive;

2. Large volumes of solvents are required, which are costly;

Contamination of the MA extract with pigments, such as chlorophyll, requires further purification. To avoid these issues, wet lipid extraction is considered as a feasible technique [53].

\section{Biodiesel Production Processes}

Microalgae biodiesel production essentially involves two main steps:

1. Extraction of oils from the biomass, including cell disruption by mechanical and chemical methods [54];

2. Conversion (transesterification) of oils (fatty acids) to biodiesel (alkyl esters).

To date, biodiesel production from algae biomass is generally performed by one of the following methods:

1. The conventional route, a two-step protocol in which algae oil is extracted and then converted to biodiesel using a catalyst, such as an acid, a base, or an enzyme.

2. Direct single step in situ production of biodiesel from algae biomass using an acid catalyst at atmospheric pressure and ambient temperature.

\begin{tabular}{|c|c|}
\hline In situ Transesterification & $\begin{array}{c}\text { Extraction- } \\
\text { Transesterification }\end{array}$ \\
\hline Heating value is high & Heating value is low \\
\hline Yield is high & Yield is low \\
\hline Simple processes in operation & Process is complex \\
\hline $\begin{array}{c}\text { Due to absence of extraction and } \\
\text { dewatering the production cost is } \\
\text { low }\end{array}$ & $\begin{array}{c}\text { Production cost is } \\
\text { low }\end{array}$ \\
\hline Avoid the potential lipid loss & $\begin{array}{c}\text { Lipid loss during } \\
\text { process }\end{array}$ \\
\hline Reduce the waste water pollutants & $\begin{array}{c}\text { Waste water pollutes } \\
\text { environment }\end{array}$ \\
\hline Less time-consuming process & $\begin{array}{c}\text { Time consumption } \\
\text { is high }\end{array}$ \\
\hline
\end{tabular}

Table 6: Differences between the use of in situ and conventional route [15].

The current microalgae-based biodiesel is mainly produced by the conventional route: extraction of the lipids from the MA biomass followed by its conversion to FAMEs and glycerol. However, such method consumes time, is energy intensive, and has high water footprint, in short, the 


\section{Petroleum \& Petrochemical Engineering Journal}

method is really costly, and difficult to be implemented in algae's crushing steps because of the rigid cell walls (Table 6).

\section{Transesterification}

Biodiesel is commonlyproduced bythetransesterification of vegetable oil, animal fat, or algal feedstock, and the exciting news is that MA could have a lot of oil as shown from Table 7 [55]. Transesterification is the reaction between an ester and an alcohol which produces a new alcohol and a new ester. In transesterification, a simple alcohol, such as methanol, is used with a catalyst.

\begin{tabular}{|c|c|}
\hline Microalgae & Oil content (\% dry wt) \\
\hline Botryococcus braunii & $25-75$ \\
\hline Chlorella sp. & $28-32$ \\
\hline Crypthecodinium cohnii & 20 \\
\hline Cylindrotheca sp. & $16-37$ \\
\hline Dunaliella primolecta & 23 \\
\hline Isochrysis sp. & $25-33$ \\
\hline Monallanthus salina & $>20$ \\
\hline Nannochloris sp. & $20-35$ \\
\hline Nannochloropsis sp. & $31-68$ \\
\hline Neochloris oleoabundans & $35-54$ \\
\hline Nitzschia sp. & $45-47$ \\
\hline Phaeodactylum tricornutum & $20-30$ \\
\hline Schizochytrium sp. & $50-77$ \\
\hline Tetraselmis sueica & $15-23$ \\
\hline
\end{tabular}

Table 7: Microalgae species and their oil content [29].

In transesterification reaction, an excess of alcohol leads to a shift in the reaction equilibrium towards product formation. Alcohols used in the transesterification reaction could be short chained, long chained, and cyclic. At the end of the reaction the excessed alcohol and glycerol, coproduced with FAME, can be separated. Methanol and ethanol are commonly utilized due to low cost, low solubility in the reaction medium, and obvious availability, however ethanol is not so commonly used because of its low reactivity towards transesterification, it is used sometimes because it can be produced from biomass so the process becomes more sustainable.

Biodiesel from MA seems to be the only renewable biofuel that has the potential to completely displace petroleumderived transport fuels without adversely affecting supply of food and other crop products. Most productive oil crops, such as oil palm, do not come close to MA in being able to sustainably provide the necessary amounts of biodiesel. Similarly, bioethanol from sugarcane is no match for MA biodiesel [9].

Chemically, transesterification involves taking a triglyceride molecule or a complex fatty acid, removing the glycerol, and creating an alkyl ester. Transesterification requires 3 moles of alcohol for each mole of triglyceride to produce $1 \mathrm{~mol}$ of glycerol and 3 mole of methyl esters (Figure 17) to achieve equilibrium. Industrial processes use 6 moles of methanol for each mole of triglyceride. This large excess of methanol ensures that the reaction is driven in the direction of methyl esters, i.e. towards biodiesel. Yield of methyl esters exceeds $98 \%$ on a weight basis [29].

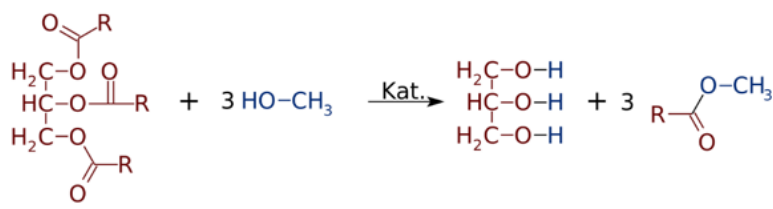

Figure 17: Generalized transesterification reaction [56].

\section{Catalysis}

Berzelius introduced the term "catalysis" early 1836 in order to explain various decomposition and transformation reactions. He assumed that special powers that can influence the affinity of chemical substances were inherent in catalyst, and Williams Ostwald, in 1895, defined a catalyst as follows: "a catalyst accelerates a chemical reaction without affecting the position of the equilibrium." Ostwald saw catalysis as a ubiquitous phenomenon that was to be explained in terms of the laws of physical chemistry. Furthermore, the catalyst is not consumed in a chemical reaction and its amount added to the reaction is much lower compared to the quantity of reagents [57].

The suitability of a catalyst for an industrial process depends mainly on the following three properties:

1. Activity (reaction speed measure);

2. Selectivity (preference for one direction of transformation);

3. Stability (lifetime of the catalyst during its operation).

The judgment of the importance level is generally difficult to answer since the demands made on the catalyst are different for each process. Today the sustainable use of energy and raw materials is of much importance, and it is preferable to optimize existing processes than to develop new ones.

For various reasons, the target quantities should be given the following order of priority: 


\section{Petroleum \& Petrochemical Engineering Journal}

Selectivity $>$ Stability $>$ Activity [57].

Generally, catalysts used for biodiesel production are categorized into three groups which are:

1. Alkalis,

2. Acids and,

3. Enzymes.

The use of alkali and acid catalysts are much more prevalent in biodiesel production in comparison to the use of enzyme catalysts [12]. Furthermore, acid and basic catalysts were categorized into homogeneous and heterogeneous catalysts. The avoidance of soap formation, and simple purification process by the use of enzyme catalysts has made them much more attractive for biodiesel production. Nonetheless, due to the longer reaction time, and a higher cost, their viability commercially can be questioned. When biocatalysts are used the main advantage is that no purification is necessary. On the other point, alkali and acid catalysts are more commonly used in transesterification because of their availability [58].

Content of $55 \%$ wt. Moreover, Johnson and Wen [59] reported conversions over $50 \% \mathrm{wt}$. using the microalgae Schizochytrium limacinum with a shorter reaction time (40 $\mathrm{min}$ ) due to the addition of chloroform in the reaction (Table 8).

\begin{tabular}{|c|c|c|}
\hline Catalysis & Advantages & Disadvantages \\
\hline \multirow{3}{*}{$\begin{array}{l}\text { Homogeneous } \\
\text { alkaline }\end{array}$} & $\begin{array}{l}\text { High reaction rate and high conversion yield } \\
\qquad(>90 \%)\end{array}$ & $\begin{array}{c}\text { Formation of soaps in the presence of FFA }(>1 \%) \text { and } \\
\text { water }(>0.06 \%)\end{array}$ \\
\hline & Low cost and widely available & Necessity of a stage for removing the catalyst \\
\hline & & $\begin{array}{l}\text { Wastewater production from biodiesel washing for } \\
\text { glycerol and remaining catalyst removal }\end{array}$ \\
\hline \multirow{3}{*}{$\begin{array}{l}\text { Heterogeneous } \\
\text { alkaline }\end{array}$} & Higher reaction rate than acid catalysts & Sensitive to FFA content in oil with soap formation \\
\hline & Easy separation of catalyst from product & Leaching of catalyst during the reaction \\
\hline & Possibility to reuse and regenerate the catalyst & \\
\hline \multirow{3}{*}{$\begin{array}{l}\text { Homogeneous } \\
\text { acid }\end{array}$} & $\begin{array}{l}\text { Not affected by water content and FFA in } \\
\text { feedstock }\end{array}$ & $\begin{array}{l}\text { Low reaction rate ( } 4000 \text { times lower than alkaline } \\
\text { catalyzed transesterification). }\end{array}$ \\
\hline & $\begin{array}{c}\text { Simultaneous esterification and } \\
\text { transesterification }\end{array}$ & Necessity for catalyst neutralization \\
\hline & & Necessity of a stage for catalyst removal \\
\hline \multirow{4}{*}{$\begin{array}{l}\text { Heterogeneous } \\
\quad \text { acid }\end{array}$} & $\begin{array}{l}\text { Not affected by water content and FFA in } \\
\text { feedstock }\end{array}$ & Leaching of catalyst during the reaction \\
\hline & $\begin{array}{l}\text { Simultaneous esterification and } \\
\text { transesterification }\end{array}$ & $\begin{array}{l}\text { High reaction temperature, high alcohol/oil molar } \\
\text { ratio and high reaction time are required }\end{array}$ \\
\hline & Easy separation of catalyst from product. & \\
\hline & Possibility to reuse and regenerate the catalyst & \\
\hline
\end{tabular}

Table 8: Summary of advantages and disadvantages of catalysis in microalgae biodiesel formation [6].

\section{Standards}

For microalgae to be sold commercially, it must meet the European (EN 14214) and American standard (ASTM D6751-10), though they are similar, they differ on some requirements. It is example of these differences the case of EN 14214, which stipulates that, polyunsaturated ( $\geq 4$ bonds) ester content and linoleic ester content must be less than $1 \%(\mathrm{~mol} / \mathrm{mol})$ and $12 \%(\mathrm{~mol} / \mathrm{mol})$, respectively [60].

The restrictions are important for biodiesel production from microalgae as the ester composition is often rich in polyunsaturated content and over these levels. Also, EN 14214 includes some parameters not present in ASTM D6751-10, like esters content, density, iodine value, and fatty acid contamination [61].

EN 14214 is more prohibitive for biodiesel from microalgae, as the boundary of cetane number is higher (51 vs 47), the maximum viscosity is lower ( $5 v s 6 \mathrm{~mm}^{2} / \mathrm{s}$ ) and the oxidative stability must be higher ( 6 vs $3 \mathrm{~h}$ ). Consequently, the ASTM D6751 standard seems to be more adapted to biodiesel from microalgae as seen in Table 9 [59]. Xu \& Miao in their journal, stated that despite the fact 
that many studies produced biodiesel from microalgae, few studies ensure that the latter satisfies the official standards. In another study, Xu \& Miao satisfied to meet the Grade S15 ASTM standard of flash point (closed cup) $\left(115^{\circ} \mathrm{C}\right)$, viscosity (5.2 $\mathrm{mm}^{2} / \mathrm{s}, 40{ }^{\circ} \mathrm{C}$ ) and acid number $(0.374 \mathrm{mg} \mathrm{KOH} / \mathrm{g}$ ). However, based on the present knowledge, methanol content
(EN 14110), sulphated ash (D874), cloud point (D2500), cold soak filterability, P content (D4951), distillation temperature (D1160), sodium and potassium (EN 14538), oxidative stability (EN 15751) have not been measured for microalgae biodiesel, as microalgae biodiesel is relatively new.

\begin{tabular}{|c|c|c|c|}
\hline Properties & Microalgal oil Biodiesel & Biodiesel fuel & ASTM biodiesel standard \\
\hline Density (kg L-1) & 0.864 & 0.838 & $0.86-0.9$ \\
\hline Viscosity (mm2s-1, cSt at 400C) & 5.2 & $1.9-4.1$ & $3.5-5.0$ \\
\hline Flash point (0C) & 115 & 75 & Min 100 \\
\hline Solidifying point (0C) & -12 & -50 to 10 & Summer max 0; \\
\hline Cold filter plugging point (0C) & -11 & -30 (Max -6.7) & Max 0.5 \\
\hline & & & - \\
\hline Acid value (mg KOH g_1) & 0.374 & Max 0.5 & - \\
\hline Heating value (MJ kg-1) & 41 & $40-45$ & 1.81 \\
\hline H/C ratio & 1.81 & & \\
\hline
\end{tabular}

Table 9: Properties of biodiesel from microalgal oil, biodiesel fuel \& ASTM biodiesel standard.

\section{Used Materials}

1. The lipid extraction, transesterification, insitutransesterification, and Purification of the microalgae species was carried out with the aid of the soxhlet extractor, density scale, petri-dishes, heaters, vacuum separator, filter paper, stop watch, and round bottom conical flasks, silica, activated carbon using various analytical reagents, on Chlorella vulgaris, Nannnochlorpsis oceania, and the $25 \mathrm{~g}$ of Thalassiosira spp supplied by Algae for future in Lisbon (Figures 18 \& 19). For the extraction of the lipids from Microalgae, the effectiveness of various reagent was experimented either by using only a single solvent or by mixing the solvents in various proportions, the procedure below was followed (Table 10);

2. Firstly, the weight of the thimble is measure after drying for few second in the dryer;

3. Then a known weight of the MA is dried, measured and transferred into the thimble which is made of cellulose,

4. After which the thimble is placed in the soxhlet extractor and, connected to water source for the condenser to cool the vapour,

5. A known volume of the reagent is placed in the conical flask, and after double checking all is set, Temperature is set to a little above the boiling point of the reagent(s) in the flask, then 3 hours was set for extraction,
6. After extraction, the thimble is dried in the over oven, and measured to compare to the initial weight before extraction,

Based on the current weight the lipid extracted is calculated using a program in Matlab, after which the extracted lipids content was calculated.

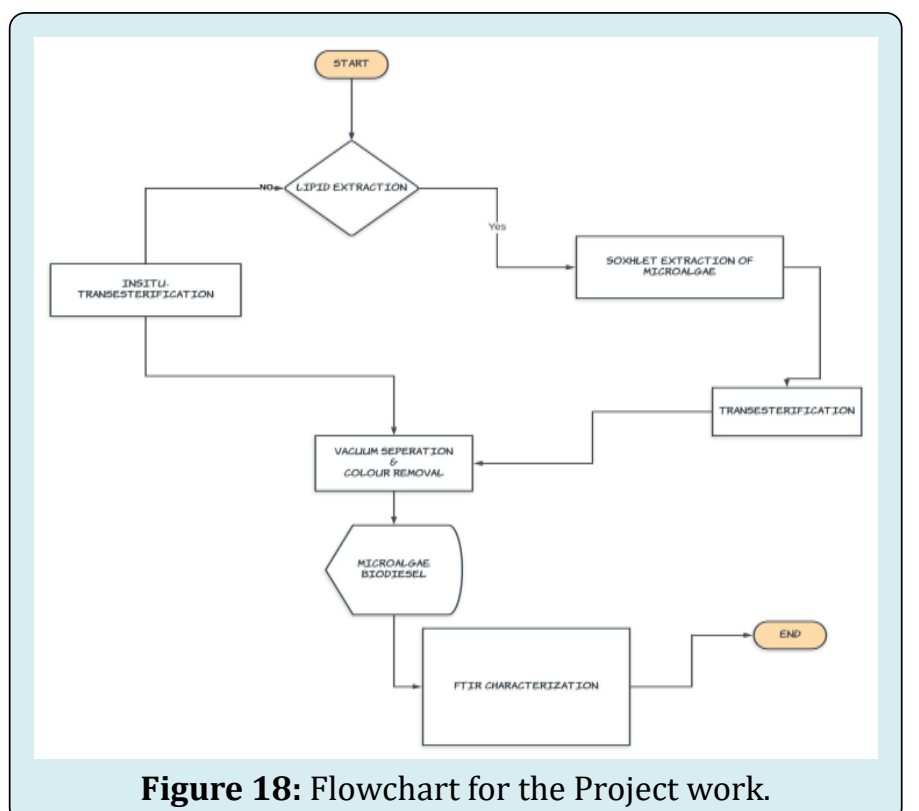


Petroleum \& Petrochemical Engineering Journal

\begin{tabular}{|c|c|c|c|c|c|}
\hline No & Microalgae Specie & Solvent & Co-Solvent & Sample Weight(g) & Ratio of Solvent/Co-Solvent \\
\hline E1 & Chlorella vulgaris & n-hexane & isopropanol & 10 & $2: 01$ \\
\hline E2 & Nannochoropsis sp. & n-hexane & isopropanol & 10 & $2: 01$ \\
\hline E3 & Chlorella vulgaris & n-hexane & isopropanol & 10 & $3: 01$ \\
\hline E4 & Chlorella vulgaris & n-hexane & isopropanol & 10 & $3: 01$ \\
\hline E5 & Nannochlropsis sp. & n-hexane & isopropanol & 10 & $3: 01$ \\
\hline E6 & Chlorella vulgaris & Isopropanol & & 10 & 1 \\
\hline E7 & Nannochlropsis spp. & Methanol & & 10 & $2: 01$ \\
\hline E8 & Thalassiosira spp. & Acetone & methanol/isopropanol & 2.5 & 1 \\
\hline E9 & Chlorella vulgaris & Methanol & & 10 & $4: 02: 01$ \\
\hline E10 & Chlorella vulgaris & Propanol & Acetone/cyclohexane & 6 & 10 \\
\hline E11 & Nannochloropsis spp. & Distilled water & & & \\
\hline
\end{tabular}

Table 10: Performed experiments using different chemical solvents.

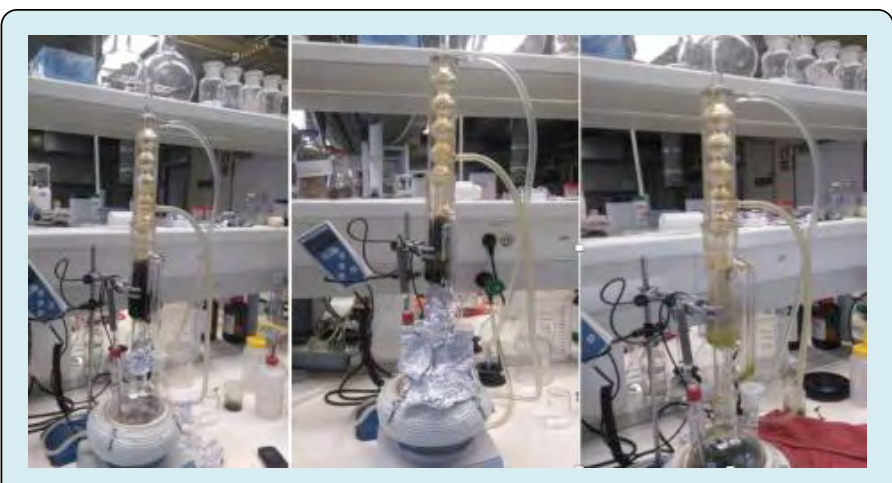

Figure 19: The stages of Microalgae Lipids extraction.

\section{Transesterification Process}

The two methods of insitu-transesterification and extract-transesterification were conducted on the three species of MA, the ratio of methanol to biomass ranged from 5:1 to 40:1, with changing temperature, time, varying different catalyst type, and finally alcohol content in the process, basically using methanol and ethanol as tabulated in Table 11. After extraction of the Lipids from the dry biomass, the extracted liquid was divided into two for transesterification, using methanol in excess with the aid of acidic/basic catalyst with the resulting fluid characterized with FTIR (Figure 20).

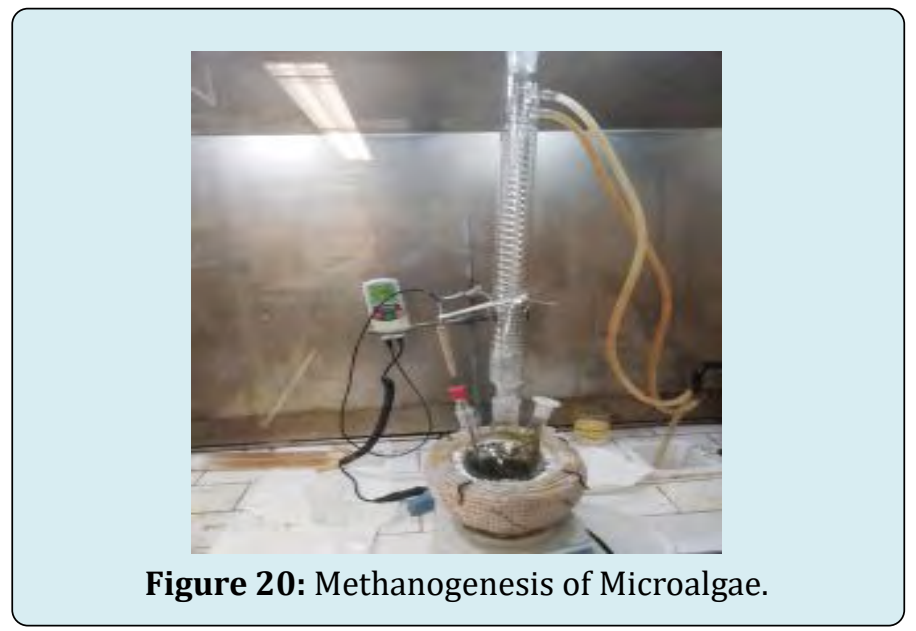

\begin{tabular}{|c|c|c|c|c|c|c|}
\hline Microalgae Type & Sample Number & Solvent & Cosolvent & Sample Weight (G) & Catalyst & Methanol/Biomass \\
\hline Chlorella & TX1 & Methanol & acetone & 25 & $\mathrm{H}_{2} \mathrm{SO}_{4}$ & 2.2 \\
\hline Chlorella & $\mathrm{T} 1$ & Methanol & acetone & 5 & $\mathrm{H}_{2} \mathrm{SO}_{4}$ & 12 \\
\hline Thalassiosira sp & $\mathrm{T} 2$ & methanol & acetone & 5 & $\mathrm{H}_{2} \mathrm{SO}_{4}$ & 12 \\
\hline Chlorella v. & $\mathrm{T} 3$ & methanol & acetone & 5 & $\mathrm{H}_{2} \mathrm{SO}_{4}$ & 16 \\
\hline Nannochlorpsis & $\mathrm{T} 4$ & methanol & acetone & 5 & $\mathrm{H}_{2} \mathrm{SO}_{4}$ & 12 \\
\hline Thalassiosira sp & T5 & methanol & acetone & 5 & $\mathrm{NaOH}$ & 12 \\
\hline Chlorella v. & $\mathrm{T} 6$ & ethanol & acetone & 5 & $\mathrm{H}_{2} \mathrm{SO}_{4}$ & 12 \\
\hline Thalassiosira sp & $\mathrm{T} 7$ & methanol & acetone & 5 & $\mathrm{NaOH}$ & 12 \\
\hline Nannochlorpsis & $\mathrm{T} 8$ & methanol & acetone & 5 & $\mathrm{CaO}$ & 16 \\
\hline Chlorella v. & $\mathrm{T} 14 \mathrm{p}$ & methanol & & 5 & $\mathrm{Na}_{2} \mathrm{CO}_{3}$ & 40 \\
\hline
\end{tabular}

Table 11: Insitu-tranesterification of microalgae under various condition. 
For insitu-transesterification the procedure are as follows;

1. A methanol of $60-80 \mathrm{ml}$ is measure into the round bottom flask, with or without a co- solvent which was acetone for proper extraction of the lipids,

2. Then the acid or basic catalyst is introduced into the flash, and it is stirred for 30 mins, after which the biomass is introduced and heated to around 65 degrees.

3. Then the mixture is separated with a vacuum pump through filtration

4. The resulting fluid is thereby characterized and decolourized with activated carbon

5. The residue is dried and weighted to see how much extraction was carried out.

\section{Results}

The FTIR spectrum shows the way the macromolecular pool are distributed. There are three main regions that relate to macromolecular pools, according to the lipid band (around $1740 \mathrm{~cm}^{-1}$ ), the amide I and amide II bands representing proteins (around 1660 and around $1540 \mathrm{~cm}^{-1}$ ) and the carbohydrate region $\left(1200-900 \mathrm{~cm}^{-1}\right)$.

The spectra of fresh samples of Chlorella vulgaris, and Nannochlorpsis spp. were characterized as shown in the Figure 21 with each peak assigned a functional group, and the peak value of Nannochloropsis spp. in bracket.

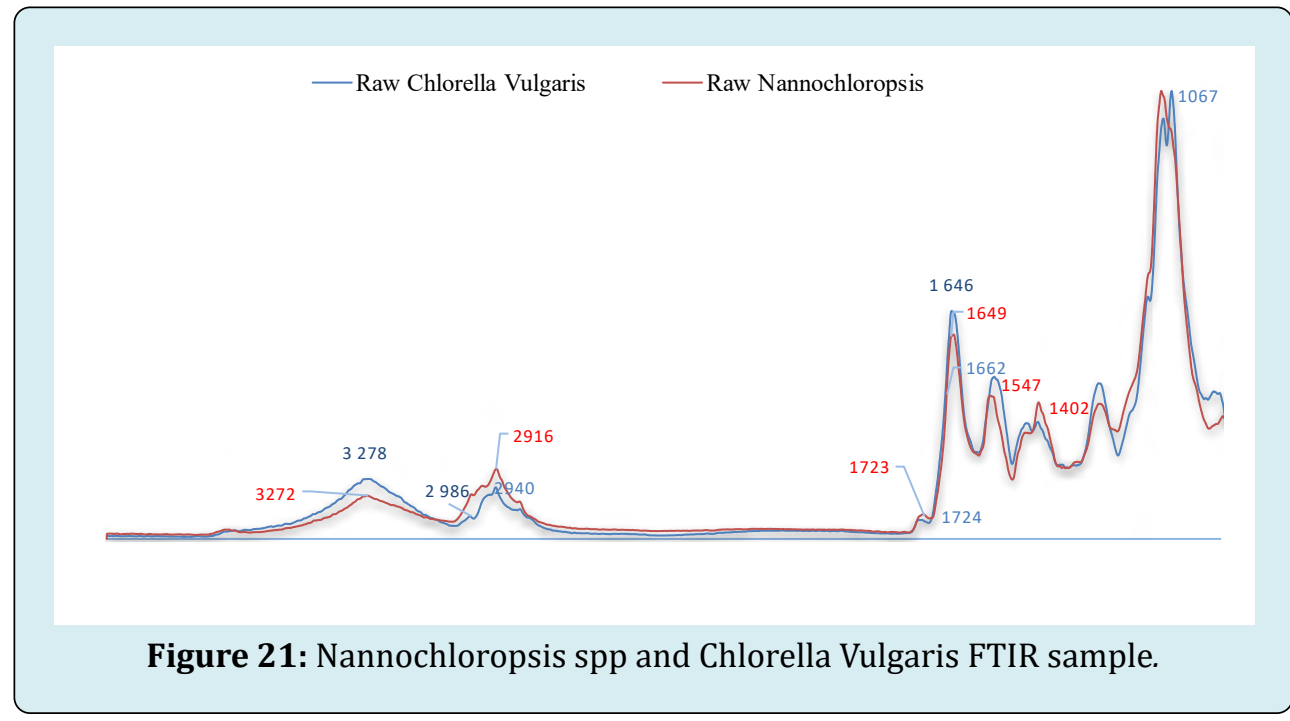

The spectra belonging to protein are characterized by two strong features at $1646(1649) \mathrm{cm}-1$ for amide I, and 1545(1547) cm-1 for (amide II). These bands were due primarily, to $\mathrm{C}=\mathrm{O}$ stretching vibration and a combination of $\mathrm{N}-\mathrm{H}$ bending and $\mathrm{C}-\mathrm{N}$ stretching vibrations in amide complexes, respectively. Lipid spectra were characterized by two sets of strong vibrations, the $\mathrm{C}-\mathrm{H}$ at $2916 \mathrm{~cm}-1$, and the $\mathrm{C}=0$ mode of the side chain from ester carbonyl group at $1742 \mathrm{~cm}-1$, carbohydrate absorption bands due to $\mathrm{C}-\mathrm{O}-\mathrm{C}$ of polysaccharides at $1146 \mathrm{~cm}-1,1067 \mathrm{~cm}-1,1049 \mathrm{~cm}-1$ respectively.

\section{Lipid Content Calculation}

After chemical extraction with various solvents, the lipid content was calculated with some algorithms inputed in a matlab form (Table 12) (Figure 22).

$$
\text { Oilpercent }=\left(\frac{\text { Bex-Aex }}{\text { Bex }}\right) * 100
$$

where;

Bex $=$ Fresh sample before extraction

Aex $=$ Fresh sample after extraction

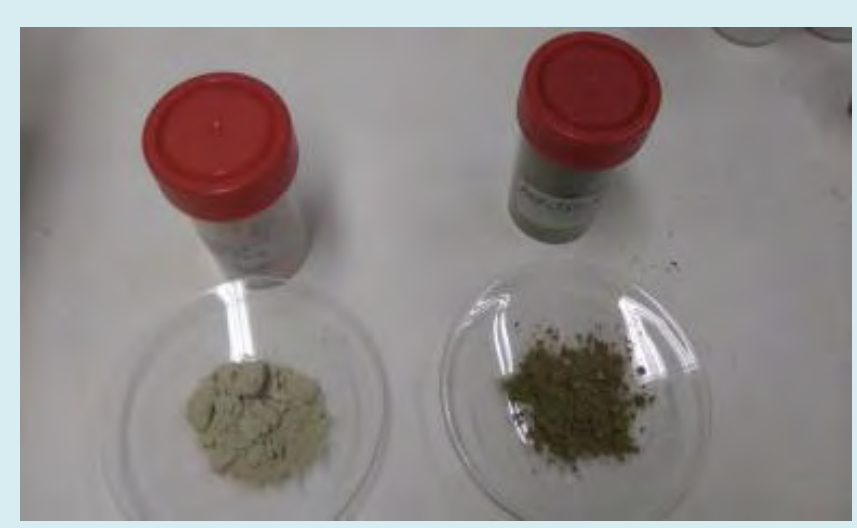

Figure 22: Thalassiosira sp. after chemical extraction on the left and after supercritical $\mathrm{Co}_{2}$ on the right. 
Petroleum \& Petrochemical Engineering Journal

\begin{tabular}{|c|c|c|c|c|}
\hline No & Microalgae Specie & Solvent & Co-Solvent & Lipid Content+Pigment (\%) \\
\hline E1 & Chlorella vulgaris & n-hexane & Isopropanol & 4 \\
\hline E2 & Nannochlropsis spp. & n-hexane & Isopropanol & 15.5 \\
\hline E3 & Chlorella vulgaris & n-hexane & Isopropanol & 8.75 \\
\hline E4 & Chlorella vulgaris & n-hexane & Isopropanol & 18.79 \\
\hline E5 & Nannochlropsis spp. & n-hexane & Isopropanol & 11.8 \\
\hline E6 & Chlorella vulgaris & Isopropanol & & 24.3 \\
\hline E7 & Nannochlropsis spp. & Methanol & & 33.4 \\
\hline E8 & Thalassiosira spp. & Acetone & methanol/isopropanol & 11 \\
\hline E9 & Chlorella vulgaris & Methanol & & 22 \\
\hline E10 & Chlorella vulgaris & Isopropanol & Acetone/cyclohexane & \\
\hline
\end{tabular}

Table 12: The Result from the chemical extraction

After the soxhlet extraction of $10 \mathrm{~g}$ of Nannochloropsis spp. with $400 \mathrm{ml}$ of methanol (E7) for 4 hours, after which the liquid extract was divided into $150 \mathrm{ml}$ of 2 parts, then transesterification was carried out with $0.54 \mathrm{~g}$ and $0.1 \mathrm{ml}$ of sodium hydroxide $(\mathrm{NaOH})$, and sulpuric acid $\left(\mathrm{H}_{2} \mathrm{SO}_{4}\right)$ for 1hour and $700 \mathrm{rpm}$ respectively on the 2 parts, giving rise to ET7 A being acid catalyzed, and ET7B being base catalyzed (Figure 23).

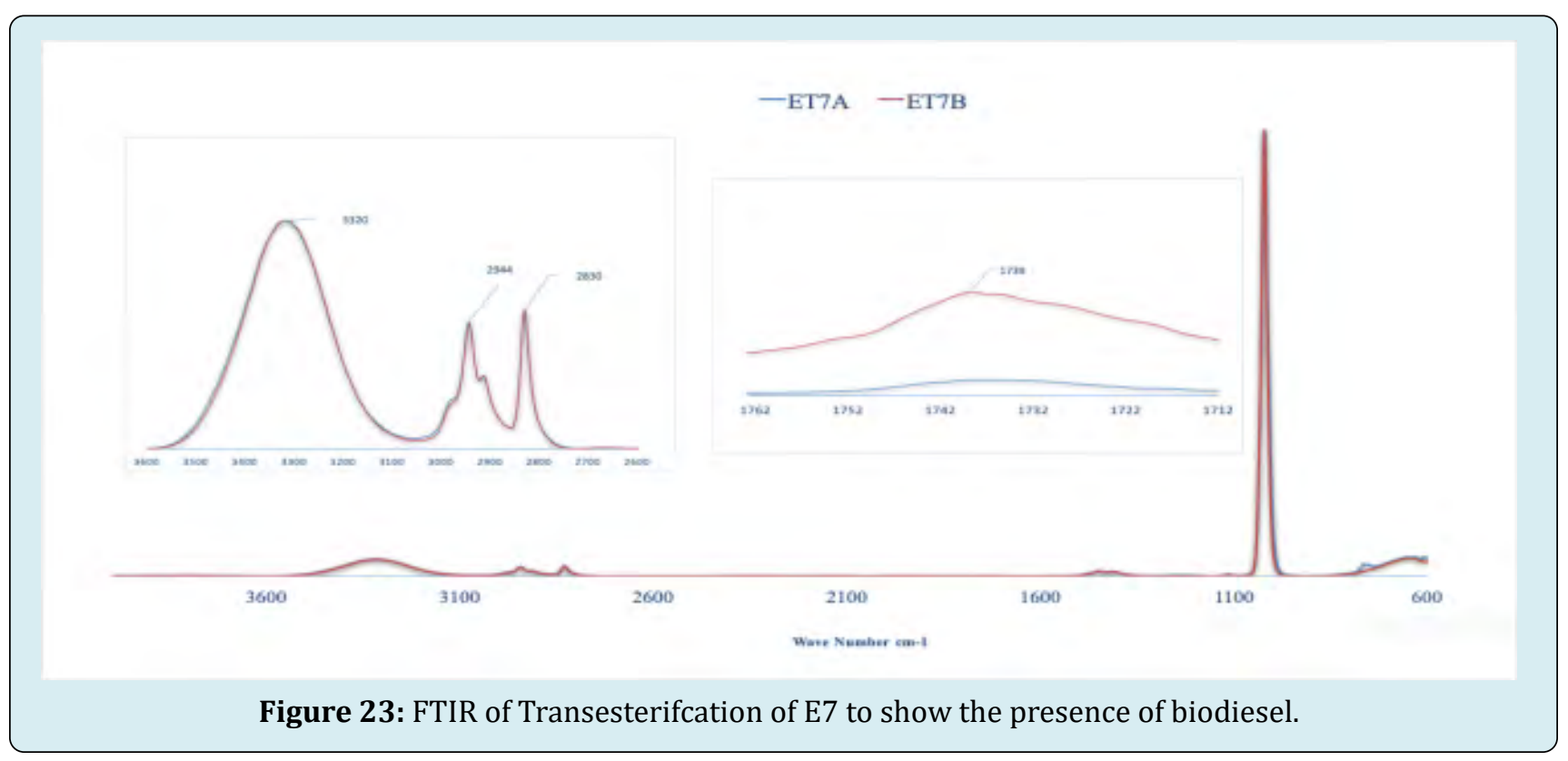

The peak of $1739 \mathrm{~cm}^{-1}$ is due to the presence of Fatty Acids due to the vibrations of $\mathrm{C}=0$ stretching of esters in ET7A, and ET7B, however ET7B showed higher intensity, which means more products were obtained in relative to ET7A.

\section{Insitu Transesterification}

Instead of the method of extraction of the lipids and further transesterification which is energy consuming, and takes much time to successfully achieve, therefore an insitutranesterication method was used with both the process of extraction and transesterification taking place at the same time using different solvents, co-solvents and catalysts.

The Table 13 below shows the insitu-transesterification of three specie of microalgae with methanol, ethanol, and acid and basic catalysts. 
Petroleum \& Petrochemical Engineering Journal

\begin{tabular}{|c|c|c|c|c|c|}
\hline Microalgae Type & Sample Number & Solvent & Cosolvent & Catalyst & Lipids Content (\%) \\
\hline Chlorella vulgaris & $\mathrm{T} 1$ & methanol & Acetone & $\mathrm{H}_{2} \mathrm{SO}_{4}$ & 22 \\
\hline Thalassiosira spp. & $\mathrm{T} 2$ & methanol & Acetone & $\mathrm{H}_{2} \mathrm{SO}_{4}$ & 47 \\
\hline Chlorella vulgaris & $\mathrm{T} 3$ & methanol & Acetone & $\mathrm{H}_{2} \mathrm{SO}_{4}$ & 27 \\
\hline Nannochlorpsis spp. & $\mathrm{T} 4$ & methanol & Acetone & $\mathrm{H}_{2} \mathrm{SO}_{4}$ & 38 \\
\hline Thalassiosira spp. & T5 & methanol & Acetone & $\mathrm{NaOH}$ & 22 \\
\hline Chlorella vulgaris & $\mathrm{T} 6$ & ethanol & Acetone & $\mathrm{H}_{2} \mathrm{SO}_{4}$ & 16 \\
\hline Thalassiosira spp. & $\mathrm{T} 7$ & methanol & Acetone & $\mathrm{NaOH}$ & 35 \\
\hline Nannochlorpsis spp. & T8 & methanol & 0 & $\mathrm{CaO}$ & 20 \\
\hline Chlorella vulgaris & T14 & methanol & 0 & $\mathrm{Na}_{2} \mathrm{CO}$ & \\
\hline
\end{tabular}

Table 13:Lipids content from Insitu-transesterification.

The table above shows the insitu-transesterification of three specie of microalgae with methanol, ethanol, and acid and basic catalysts.

In the Figure 24 below the diatom Thalassiora spp. microalgae of $5 \mathrm{~g}$ is used in an insitu-transesterifcation process with $60 \mathrm{ml}$ of methanol, $20 \mathrm{ml}$ of acetone, and $0.5 \mathrm{ml}$ of $\mathrm{H} 2 \mathrm{SO} 4$ for 4 hours in the T2 sample, and the catalyst is replaced with $0.54 \mathrm{~g}$ of $\mathrm{NaOH}$ in $\mathrm{T} 7$. A peak of $1741 \mathrm{~cm}^{-1}$ in the sample T7 shows the presence of Fatty Acids esters due to the vibration of the $\mathrm{C}=0$ stretching of the esters, and $\mathrm{T} 7$ was visually sighted to contain white substances possibly soap, also the peaks 2943 and $2835 \mathrm{~cm}^{-1}$ is due to Lipid carbohydrate Mainly due to the asymmetrical vibration of CH2 stretching.

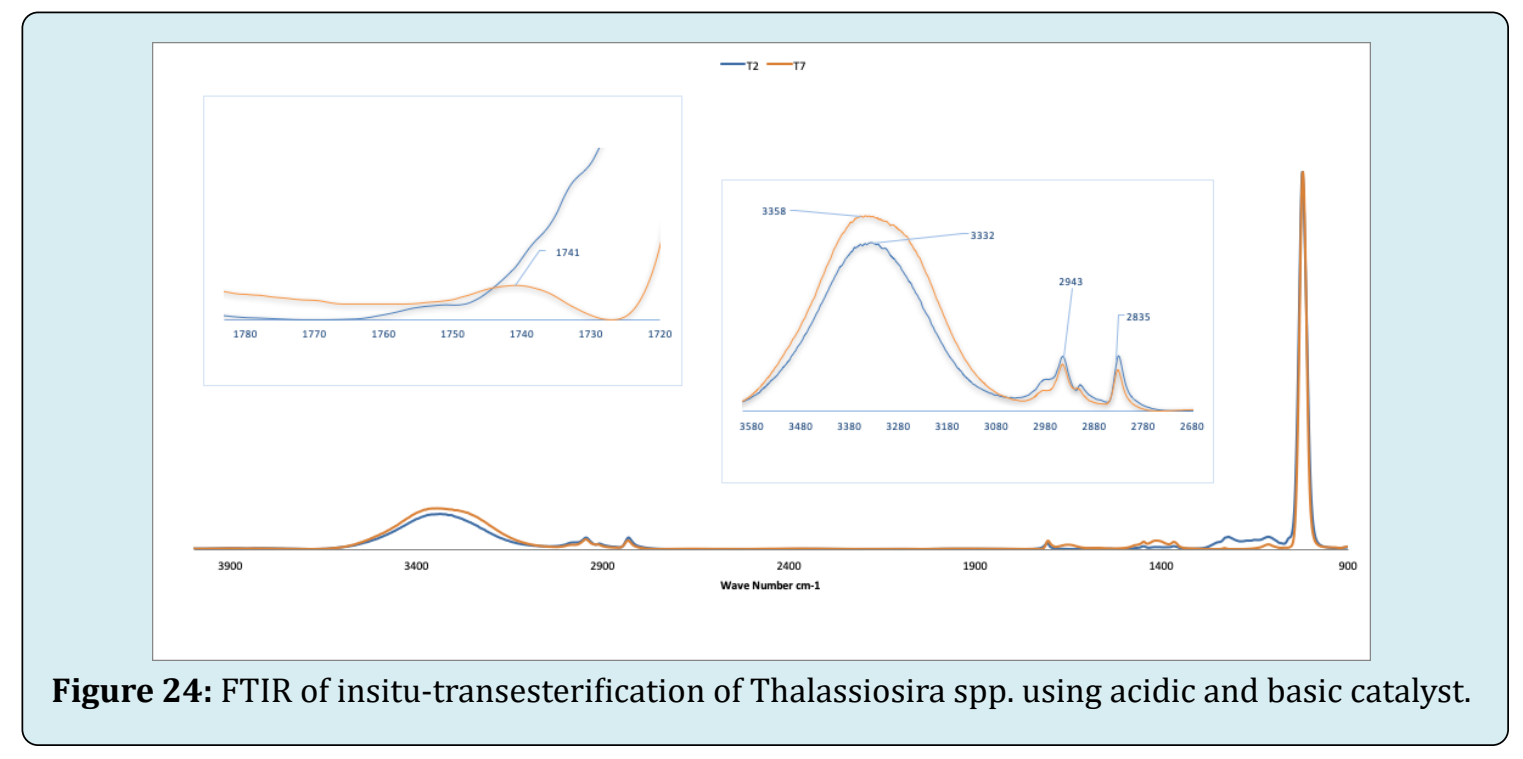

In the Figure 25 below the microalgae chlorella T1B is catalyzed by $0.5 \mathrm{ml}$ of sulphuric acid, T3B is catalyzed by $1 \mathrm{ml}$ of sulphric acid and the solvent is replaced by ethanol in T6B, and finally the Catalyst is replaced with $\mathrm{Na}_{2} \mathrm{CO}_{3}$ in T14PB. A peak of $1740 \mathrm{~cm}-1$ in the sample T1B shows the presence of Fatty Acids esters due to the vibration of the $\mathrm{C}=0$ stretching of the esters, and T14PB was visually sighted to contain white substances possibly soap, also the peaks 2943 and $2835 \mathrm{~cm}^{-1}$ is due to Lipid - carbohydrate Mainly due to the asymmetrical vibration of $\mathrm{CH} 2$ stretching. 


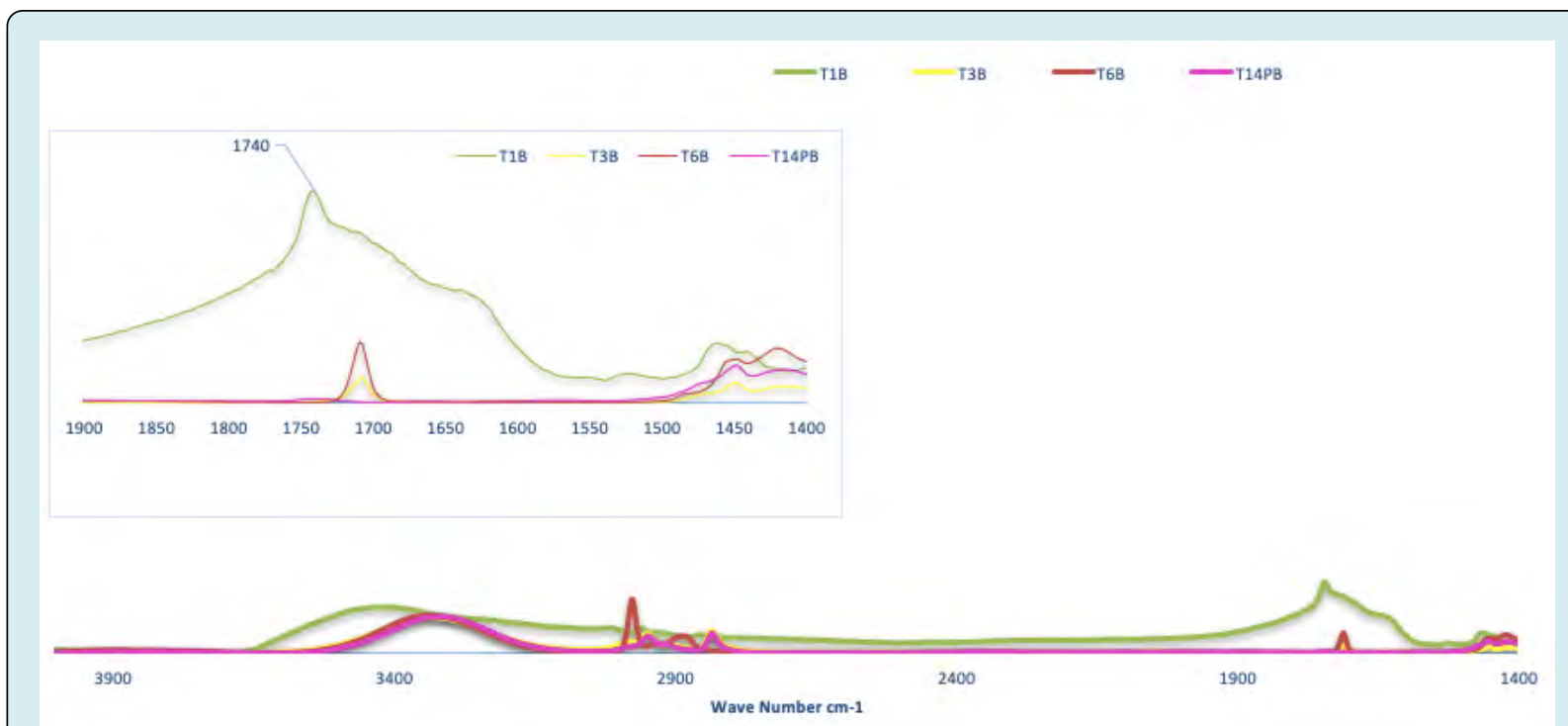

Figure 25: FTIR of the insitu-transesterification of chlorella vulgaris with methanol and ethanol.

Also, the Figure 26 shows the FTIR spectra from the product of insitu-transesterifcation of Nannochlorpsis spp. microalgae,the sample T4B being a product of transesterification with methanol, acetone and acid as catalysts, and T8B a product of using just methanol, no acetone and calcium Oxide $(\mathrm{CaO})$ calcinated at 900 degrees celcius .The peak of 1716 in the sample T4B shows the presence of Fatty Acids esters due to the vibration of the $\mathrm{C}=0$ stretching of the esters, also the peaks 2951 and $2833 \mathrm{~cm}^{-1}$ is due to Lipid - carbohydrate Mainly due to the asymmetrical vibration of $\mathrm{CH}_{2}$ stretching.

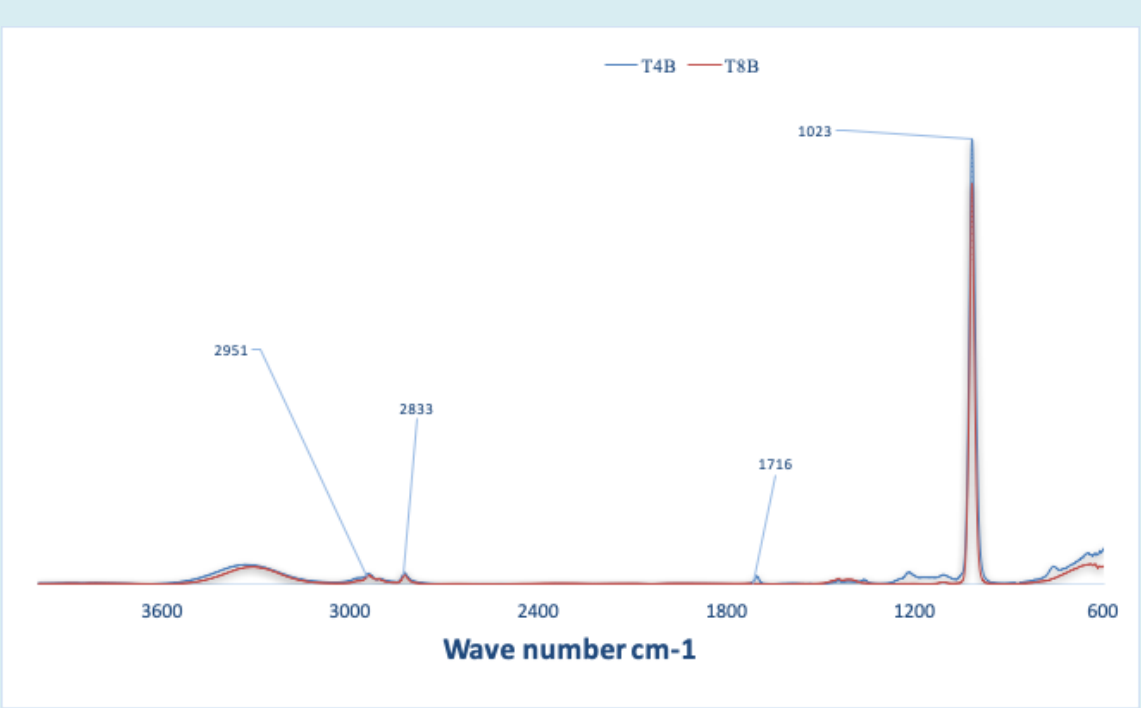

Figure 26: FTIR spectra of the product of the insitu-transesterification of Nannochloropsis spp. with acidic and basic catalysts.

Figure 27, shows the levelling of the wave length between 2850 to $3200 \mathrm{~cm}^{-1}$ of Nannochlorpsis sp. microalgae, in the quest to remove the lipids, it shows methanol is a good solvent for the task.
Comparing the raw sample of the microalgae used, it evident that the band belonging to Lipid is reduced to prominent level. 


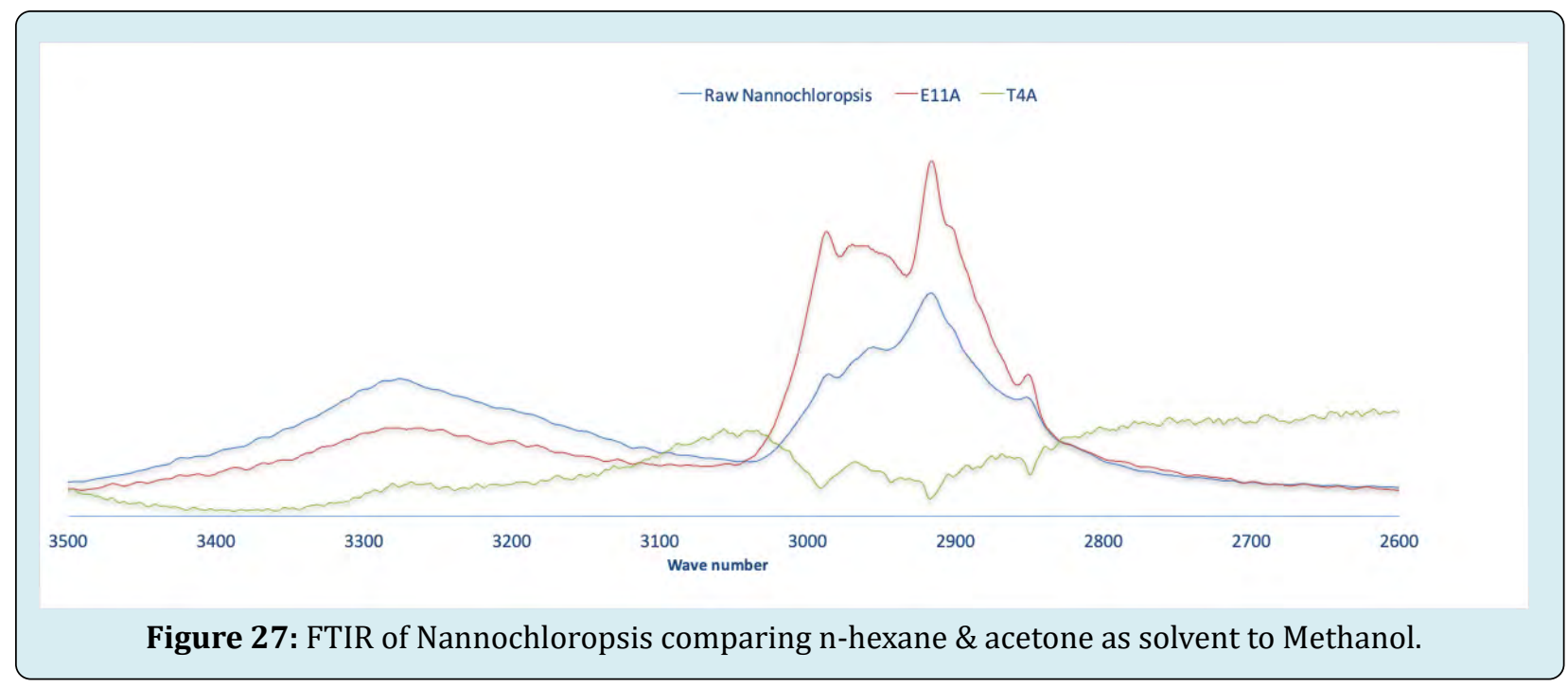

\section{Decoloziation of the Biodiesel}

The microalgae biodiesel produced from acid catalysis was quite darker, compared to the Biodiesel from basic catalysis which maintained the original green colour of the pigments contained in the microalgae sample. To meet the standard colour of colourless to yellow, activated charcoal of $0.3 \mathrm{~g}$ was added, and the mixture allowed to react for around 20 mins which after, the method of filtration was used to separate the mixture Figure $28 \mathrm{a} \& \mathrm{~b}$.

A change of colour was obvious and, the activated charcoal retrieved was seen to be still active for reuse.

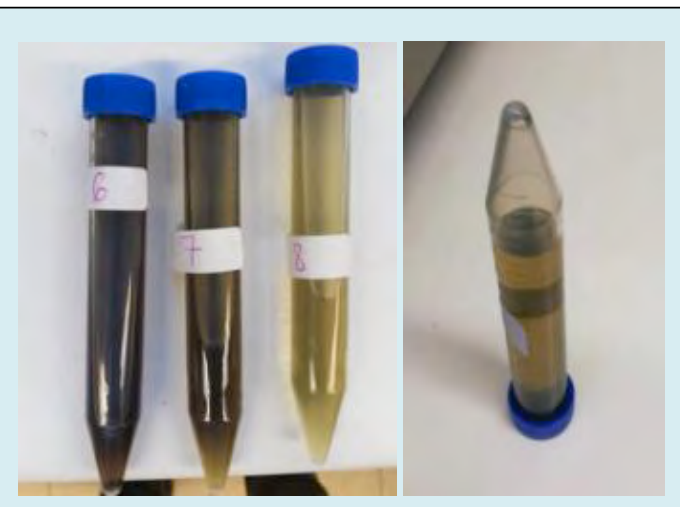

Figure 28a\&b: Sample T6B, T7B, and T8B after reaction with activated carbon

\section{Conclusion}

The result proved that the best solvent for Lipid extraction proved to be acetone or combination of acetone and methanol based on 3 species of microalgae which are Nannochloropsis spp., Thalassiosira spp., and Chlorella vulgaris. Currently, esterification and transesterification are the most commonly applied technology in the production of biofuel. For the paper, Insitu-transesterifcation as method of production of biodiesel, was used because it is becoming rather attaractive and highly effiecient in terms of bio-fuel production. The main draw-back of this process is that it consumes lots of solvents, water and it is highly energy intensive (about $30 \mathrm{ml} /$ seconds).

Biodiesel is a non-toxic, renewable, biodegradable, and more environmental friendly fuel which appears to be an alternative fuel to petro-diesel, but in the future other thermochemical methods, like hydrothermal liquefaction and pyrolysis would be needed to transform the residue left after making biodiesel into other combustible products. Although, the industrial scale of production of biofuels from microalgae is at its early stage, it still represents a sustainable solution for transportation fuel that could serve as a replacement to the petro-diesel, since there is a possibility to produce microalgal biodiesel to satisfy the fast-paced rise in the energy demand within the restraints of land and water resources.

The biorefinery approach of biodiesel can lead to a more economical viable fuel which could replace petroleum based fuels or compete with other renewable energy technologies such as wind, solar, geothermal and other forms. Microalgae biodiesel is not yet economically viable despite the high potential in terms of productivity and sustainability. Most algae based biofuel concepts still require significant investment in research and development to make the process really become commercially viable.

The possibility of Microalgal farming should be incorporated with flue gas $\mathrm{CO}_{2}$ mitigation and wastewater treatment to reduce the operating cost, thereby ensuring 


\section{Petroleum \& Petrochemical Engineering Journal}

a cost-effective farming. Microalgae have the ability of decarbonization of flue gases as proven by the cultivation of these organisms to utilize the nitrogen and phosphorus as nutrients from waste water sources as a form of wastewater bioremediation. Moreover, microalgal biodiesel can reduce the emission of NOx. Microalgae produce valuable coproducts or byproducts such as $\mathrm{H}_{2}$, ethanol, biopolymers, proteins, cosmetic products, carbohydrates, fertilizer, animal feed, biomass residue etc.

Microalgae cultivation does not require fertilizer, herbicides and pesticides, also from the combustion point of view the heating value of Microalgal biodiesel is more than that of other terrestrial plants, which is around $41 \mathrm{MJ} / \mathrm{kg}$ as compared to the $37 \mathrm{MJ} / \mathrm{kg}$ of soybeans or rapeseed. Changyan Yang also concluded that pyrolysis temperature of MA is mainlyat $400-550{ }^{\circ} \mathrm{C}$, which is slightly lower than the direct pyrolysis of lignocellulosic biomass (commonly $450-650^{\circ} \mathrm{C}$ ).

The research work of Yulin Hua showed that methanol was identified as the most effective reaction medium for the production of bio-crude oil from low-lipid microalgae. Afterwards, the effects of other reaction conditions (residence time, biomass/solvent mass ratio, and reaction temperature) on the liquefaction in methanol were examined. Liquefaction experiments at $225^{\circ} \mathrm{C}$ for 60 min with $1: 5$ biomass/solvent mass ratio resulted in the highest bio-crude oil yield of 85.5 $\mathrm{wt} \%$, along with a higher heating value (HHV) of $30.6 \mathrm{MJ} / \mathrm{kg}$.

\section{References}

1. Jonathan BS, Burkart MD, Mayfield SP, Smith VH (2016) Recent progress and future challenges in algal biofuel production. F1000Research, pp: 1-7.

2. Schenk PM, Thomas-Hall SR, Stephens E, Marx UC, Mussgnug, et al. (2008) Second Generation Biofuels: High-Efficiency Microalgae for Biodiesel Production. Bioenerg Res 1: 20-43.

3. Deng X, Yajun L, Xiaowen F (2009) Microalgae: A promising feedstock for biodiesel. African Journal of Microbiology Research 3(13): 1008-1014.

4. Gopinathan C (2004) Marine microalgae. Proceedings of Ocean Life Food and Medicine ExpoChennai, India.

5. Callieri C, Stockner JG (2002) Freshwater autotrophic picoplankton: A review. Journal of Limnology 61(1): 1-14.

6. Williams PJB, Laurens LML (2010) Microalgae as biodiesel and biomass feedstocks: Review and analysis of the biochemistry, energetics and economics. Energy Environ Sci 3(5): 554-590.
7. Garofalo R (2010) Algae and aquatic biomass for a sustainable production of 2nd generation biofuels. European Commission, Pobranoz, lokalizacji.

8. Alcaine AA (2010) Biodiesel from Microalgae. Royal School of Technology, Swden, pp: 1-92.

9. Chisti Y (2008) Response to reijnders: do biofuels from microalgae beat biofuels from terrestrial plants? Trends Biotechnol 26(7): 351-352.

10. Zachleder V, Bišová K, Vítová M (2016) The Cell Cycle of Microalgae. In: Borowitzka M (Ed.), The Physiology of Microalgae. Springer, pp: 3-46.

11. Defenderauto, Types-of-cells.

12. Hanna MA, Fangrui M (1999) Biodiesel production: a review. Bioresource Technology 70(1): 1-15.

13. Mata TM, Martins AA, Caetano NS (2010) Microalgae for biodiesel production and other applications: a review. Reneweable and Sustaintainable Energy Reviews 14(1): 217-232.

14. Dragone G, Daniel Fernandes B, Vicente A, Teixeira JA (2010) Third generation biofuels from microalgae. In: Méndez-Vilas A (Ed.), Current Research, Technology and Education Topics in Applied Microbiology and Microbial Biotechnology. Formatex Research Center, Spain, pp: 1355-1366.

15. Becker EW (1994) Microalgae: Biotechnology and Microbiology. Cambridge Studies in Biotechnology, Cambridge University Press.

16. Carvalho AP, Silva SO, Baptista JM, Malcata FX (2011) Light requirements in microalgal photobioreactors: an overview of biophotonic aspects. Appl Microbiol Biotechnol 89(5): 1275-1288.

17. Silverstein A, Silverstein V, Silverstein L (2008) Photosynthesis. Twenty-First Century Books, pp: 80.

18. Chen J, Ji L, Dong W, Xiaolei Z, Tyagi RD (2018) The potential of microalgae in biodiesel production. Renewable and Sustainable Energy Reviews 90: 336346.

19. Ferreira AF, Soares Dias AP, Silva CM, Costa M (2016) Effect of low frequency ultrasound on microalgae solvent extraction: Analysis of products, energy consumption and emissions. Algal Research 14: 9-16.

20. Suganya T, Varman M, Masjuki HH, Renganathan S (2016) Macroalgae and microalgae as a potential source for commercial applications along with biofuels production: a 


\section{Petroleum \& Petrochemical Engineering Journal}

biorefinery approach. Reneweable and Sustainable Energy Reviews 55: 909-941.

21. Alberici S, Gemma T (2013) UK biofuels industry overview. Input to Draft PI, Ecofys, London.

22. Els P (2017) Emissions regulations force manufacturers across the world to clean up their act. Real driving Emissions. Pobranoz lokalizacji.

23. Hombach LE, Cambero C, Sowlati T, Walther G (2016) Optimal design of supply chains for second generation biofuels incorporating European biofuel regulations. Journal of Clean Production 133: 565-575.

24. Directive (2006) Review of EU Biofuels. exercise, Public consultation.

25. Project TE (2018) Green Living Energy Efficient Cut Down on Waste Immediate Change Long Term Effect Sustainable Living. Pobranoz, lokalizacji.

26. Amanor-Boadu V, Pfromm P, Nelson R (2014) Economic feasibility of algal biodiesel under alternative public policies. Renewable Energy 67: 136-142.

27. Sawaengsak W, Silalertruksa T, Bangviwat A, Gheewala SH (2014) Life cycle cost of biodiesel production from microalgae in Thailand. Energy for Sustainable Development 18(1): 67-74.

28. Davis R, Aden A, Pienkos PT (2011) Techno-economic analysis of autotrophic microalgae for fuel production. Appl Energy 88(10): 3524-3531.

29. Chisti $Y$ (2007) Biodiesel from microalgae. Biotechnology Advances 25(3): 294-306.

30. Jorge Alberto VC, Grequede Morais M (2014) An Open Pond System for Microalgal Cultivation. In: Pandey A, Chisti Y, Duu-Jong L, Soccol CR (Eds.), Biofuels from Algae. Elsevier BV, pp: 1-22.

31. Huang Q, Jiang F, Wang L, Yang C (2017) Design of Photobioreactors for Mass Cultivation of Photosynthetic Organisms. Green Chemical Engineering-Review 3(3): 318-329.

32. Sompech K, Chisti Y, Srinophakun T (2012) Design of raceway ponds for producing microalgae. Biofuels 3(4): 387-397.

33. MESA (2015) Marine Algae. Pobranoz lokalizacji.

34. Roesijadi G, Susanne JB; Snowden-Swan, Lesley J, Zhu Y (2010) Macroalgae as a biomass feedstock: a preliminary analysis. Department of Energy under contract, Pacific
Northwest National Laboratory, Richland, WA.

35. Priyadarshani I, Biswajit R (2012) Commercial and industrial applications of micro algae-A review. J Algal Biomass Utln 3(4): 89-100.

36. Subitec, Uses of algae, Application and uses of algae. Pobranoz, lokalizacji.

37. Subitec, Added-value-in-algae-cultivation. Pobranoz, lokalizacji.

38. Hamed I (2016) The Evolution and Versatility of Microalgal Biotechnology: A Review. Comprehensive Reviews in Food Science and Food Safety 15(6): 11041123.

39. Spolaore P, Joannis-Cassan C, Duran E, Isambert A (2006) Commercial applications of Microalgae- review. Journal of Bioscience and Bioengineering 101(2): 87-96.

40. Pangestuti R, Se-Kwon K (2011) Biological activities and health benefit effects of natural pigments derived from marine algae. Journal of Functional Foods 3(4): 255-266.

41. Brown MR, Mular M, Miller I, Farmer C, Trenerry C (1999) The vitamin content of microalgae used in aquaculture. Journal of Applied Phycology 11: 247-255.

42. Borowitzka MA (1988) Vitamins and fine chemicals from micro-algae. Micro-algal biotechnology, pp: 153-196.

43. Ferreira A, Ribeiro B, Marquesa P, Ferreira AF, Dias AP (2017) Scenedesmus obliquus mediated brewery wastewater remediation and $\mathrm{CO} 2$ biofixation for green energy purposes. Journal of Cleaner Production 165: 1316-1327.

44. Pulz 0, Gross W (2005) Valuable products from biotechnology of microalgae. Appl Microbiol Biotechnol 65(6): 635-648.

45. Hallmann A (2007) Algal transgenics and biotechnology. Transgenic Plant Journal 1(1): 81-98.

46. Hidalgo P, Toro C, Ciudad G, Navia R (2013) Advances in direct transesterification of microalgal biomass for biodiesel production. Rev Environ Sci Biotechnol 12: 179-199.

47. Molina Grima E, Ibáñez González MJ, Giménez Giméne (2012) Solvent Extraction for Microalgae Lipids. In: Borowitzka MA, Moheimani NR (Eds.), Algae for Biofuels and Energy. Springer Dordrecht Heidelberg ,New York, London, pp: 187-205.

48. Oilgae. Pobranoz, lokalizacji. 
49. Kiman S, Bitrus Kwaji H, Babagana G (2015) Lipid Extraction And Transesterification Techniques of Microalgae-A Review. International Journal of Molecular Sciences 26(1): 26-37.

50. Letcher TM (2007) Thermodynamics, Solubility and Environmental Issues. Elsevier Science, pp: 492.

51. Freund $\mathrm{P}$ (2016) Properties of $\mathrm{CO}_{2}$ and carbon-based fuels. In: Metz B, Davidson 0, Coninck Hd, Loos H, Meyer L (Eds.), IPCC Special Report on Carbon dioxide Capture and Storage. UNEP, Cambridge university press, pp: 383.

52. Supercritical fluid. Pobranoz, lokalizacji.

53. Stewart G(2003) Dry Cleaning with Liquid Carbon Dioxide. Green Chemistry Using Liquid and SCO 2: 215227.

54. Park JH, Hong JY, Jang HC, Oh SG, Kim SH (2012) Use of Gelidium amansiias a promising resource for bioethanol: a practical approach for continuous diluteacid hydrolysis and fermentation. Bioresour Technol 108: 83-88.

55. Otera J (1993) Transesterification. Chemical Reviews 93(4): 1449-1470.
56. King WM (2012) Major Roles of Biological Lipids. Pobranoz, lokalizacji.

57. Hagen J (2006) Industrial Catalysis: A Practical Approach. $2^{\text {nd }}(E d n$.$) , Wiley-Vch Verlag GmbH \& Co. KGaA,$ Weinheim, Germany.

58. Fukuda H, Kondo A, Noda H (2001) Biodiesel fuel production by transesterification of oils. J Biosci Bioeng 92(5): 405-416.

59. Johnson MB, Wen Z (2009) Production of biodiesel fuel from the microalga Schizochytrium limacinum by direct transesterification of algal biomass. Energy Fuels 23(10): 5179-5183.

60. Knothe G (2010) Biodiesel and renewable diesel: A comparison. Progress in Energy and Combustion Science 36(3): 364-373.

61. Koberg M, Cohen M, Ben-Amotz A, Gedanken A (2011) Bio-diesel production directly from the microalgae biomass of Nannochloropsis by microwave and ultrasound radiation. Bioresource Technology 102(5): 4265-4269. 